\title{
FUNDAMENTOS PARA UMA LEITURA CRÍTICA DE HANS KELSEN NO SÉCULO XXI: EM BUSCA DE UM MODELO KELSENIANO CLÁSSICO*
}

FOUNDATIONS FOR A CRITICAL READING OF HANS KELSEN IN THE XXI CENTURY: TOWARDS

A KELSENIAN CLASSICAL MODEL

José Antonio Siqueira Pontes ${ }^{* *}$

\begin{abstract}
Resumo:
O estudioso das obras de Kelsen sabe que a Teoria Pura do Direito não é um livro, mas uma escola que evoluiu no decurso do século XX. A identificação de um único "modelo kelseniano clássico" na filosofia do direito não é possível por força da complexidade de seu pensamento. É possível, no entanto, apresentar as ideias de Kelsen segundo seus postulados mais marcantes. Para tanto, pode-se afirmar que Kelsen buscou elaborar um modelo epistemológico purista para a ciência do direito, tendo se destacado por evitar toda metafísica e ao mesmo tempo formular um método racionalista rigoroso e sistemático. A intenção de Kelsen foi erguer um monumento teórico, afirmando a vitória da razão pura como a melhor e definitiva proposta para o conhecimento científico do direito. Dentre os problemas que sua proposta teve de enfrentar estão a distinção entre direito e moral, a separação dos conceitos de validade e eficácia como corolário de seu dualismo metodológico do ser e do deverser e a relação entre razão e vontade. Todas essas questões Kelsen pretendeu ver resolvidas com seu argumento transcendental. Mas a análise rigorosa dos problemas em torno da norma fundamental (Grundnorm) revela, dentre muitas, quais foram as críticas pertinentes que realmente colocaram em xeque o rigor analítico da Teoria Pura do Direito, levando inclusive seu autor a mudar de opinião no curso da obra. O objetivo aqui é revisitar esse momento histórico com uma abordagem abrangente, já que trata de importantes fundamentos de qualquer investigação na jurisprudência atual.
\end{abstract}

Palavras-chave: Hans Kelsen. Teoria pura do direito. Norma fundamental (Grundnorm). Validade. Neokantismo. Immanuel Kant.

\begin{abstract}
:
Kelsen's students know that the Pure Theory of Law is not a book but a "school" that has evolved during the twentieth century. The identification of a single "classic model of Kelsen" in philosophy of law cannot be achieved, due to the complexity of his thought. It is possible, however, to present Kelsen's ideas according
\end{abstract}

Esse artigo é dedicado aos alunos iniciantes nos estudos de Filosofia do Direito, do primeiro ao quinto ano dos cursos de graduação, ou àqueles estudiosos maduros dotados da habilidade de se colocar como a primeira vez defronte aos assuntos já “conhecidos", em busca da confirmação dos fundamentos. É resultante da revisão da primeira parte da dissertação de mestrado defendida e aprovada em 2002, na Faculdade de Direito da Universidade de São Paulo, sob a orientação do Prof. Dr. Livre Docente Alaôr Caffé Alves.

** Professor na área de Filosofia do Direito na FACAMP (Faculdades de Campinas), mestre e doutor em Filosofia do Direito pela Universidade de São Paulo. E-mail: jspontes@gmail.com. 
to his most striking statements. One can affirm that Kelsen sought to develop a purist epistemological model for a science of law, which has become prominent by avoiding all metaphysics and also by formulating a rigorous and systematic rational method. Kelsen's intention was to raise a theoretical monument, claiming the ultimate victory of pure reason as the best and final proposal to the scientific knowledge of the law. Among the problem that his proposal had to face was the distinction between law and morality, the separation of the concepts of validity and effectiveness as a corollary of his methodological dualism of "is" and "ought" and the relationship between reason and will. Kelsen wanted to solve all these issues by his the transcendental argument. But a rigorous analysis of these problems surrounding the basic norm (Grundnorm) reveals that critics were pertinent and really have challenged the analytical rigor of the Pure Theory of Law, leading the author to change his ideas in the course of the several editions of the book. The purpose here is to revisit this historical moment from a comprehensive approach, since it's in the basis of any investigation in jurisprudence nowadays.

Keywords: Hans Kelsen. Pure theory of law. Fundamental norm (Grundnorm). Validity. Neokantism. Immanuel Kant.

1. A validade segundo o modelo clássico de Kelsen

O conceito de validade apresenta-se na Teoria Pura do Direito como o conceito mais importante para a construção do modelo de Kelsen, pois é por meio dele que se identificam todas as características da concepção de uma teoria do direito que se pretende "depurada". Para explicitar, inicialmente, as bases características desse conceito é interessante a análise de Stanley Paulson, que identifica a obra de Kelsen como uma espécie de revolução nas teorias do direito no ponto em que se encontravam no início do século XX. E o Autor associa a teoria de Kelsen como sendo uma estratégia em analogia com o que significou a doutrina kantiana à sua época.

Para Paulson, assim como Kant propôs uma terceira via alternativa, primeiro, às filosofias que negavam a possibilidade de um conhecimento estável acerca dos objetos e, segundo, às que julgavam já tê-lo encontrado, Kelsen, de modo semelhante, apresenta uma terceira via às teorias jurídicas que uniam o direito à moral e as que uniam o direito aos fatos. As primeiras julgavam ter encontrado um direito "em-si" numa ordem moral transcendente e as segundas acabavam por negar uma normatividade ao equiparar o ser ao dever-ser.

Desde el punto de vista sistemático Kelsen es - esta mi primera tesis - kantiano en la medida en que intenta encontrar un "término medio" entre la teoría empírica del derecho y la doctrina del derecho natural, de la misma manera como Kant antes que él había buscado un "término medio" entre el empirismo escéptico y el racionalismo dogmático. (PAULSON, 2000, p. 78). 
O pensamento kelseniano surge, nessa medida, para afastar a "antinomia" que se apresentava entre os teóricos da tradição de sua época: o conceito de direito devia ser afastado de uma moral ou de um jusnaturalismo que afirma uma ordem natural e absoluta dos valores, bem como evitar um realismo jurídico reducionista que não explica uma normatividade independente dos fatos. Paulson apresenta o seguinte quadro representativo da teoria de Kelsen na tradição em que surgiu (PAULSON, 1992, p. xxvi):

\begin{tabular}{|c|c|c|}
\hline & \multicolumn{2}{|c|}{ 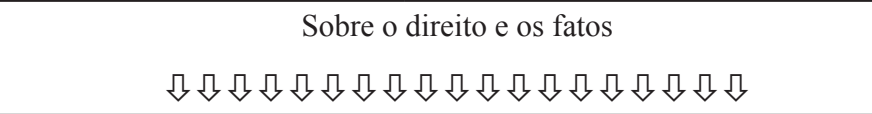 } \\
\hline $\begin{array}{l}\text { Sobre o direito e a } \\
\text { moral } \\
\qquad 囚 \Omega \Omega \Omega \Omega\end{array}$ & $\begin{array}{c}\text { Reducionismo cético: } \\
\text { direito = fato. } \\
\text { Eliminação da normatividade. }\end{array}$ & $\begin{array}{c}\text { Tese da Separação: } \\
\text { Direito vs. fato. } \\
\text { Admissão de uma normatividade. }\end{array}$ \\
\hline $\begin{array}{l}\text { Tese moralista: } \\
\text { direito = moral. }\end{array}$ & - & Jusnaturalitas \\
\hline $\begin{array}{l}\text { Tese positivista: } \\
\text { direito vs. moral. }\end{array}$ & Positivistas empiristas & Kelsen \\
\hline
\end{tabular}

A referida "antinomia", pensada no campo do direito, bem como a situação de Kelsen como um terceiro gênero teórico em relação à tradição, são descritas pelo próprio Paulson como problemáticas, já que a pluralidade de teorias com as quais Kelsen dialoga é de tal monta que possivelmente pareceria ao leitor mais experiente uma simplificação exagerada:

Si hacemos una retrospectiva de la historia de la filosofía del derecho surge sin duda desde el principio una gran desconfianza en la clasificación de un buen número de iusfilósofos, con exactitud en dos campos, o sea teóricos empiristas y iusnaturalistas. Las posiciones de aquellos antecesores y contemporáneos con los que controvierte Kelsen, por ejemplo, Ernst Rudolf Bierling, Karl Binding, Eugen Ehrlich, Otto von Gierke, Georg Jellinek, Rudolf von Ihering, Hermann Kantorowicz, Emil Lask, Hugo Preuß, Gustav Radbruch, Félix Somló, Rudolf Stammler, August Thon, Max Weber, Bernhard Windscheid e Ernst Zitelman, un poco depués Hermann Heller, Carl Schmitt y Rudolf Smend, y por último Herbert Hart y Alf Ross, tan diferentes que es muy difícil comprobar la realidad histórica de aquello que hasta ahora se llama antinomia jurídicofilosófica. (PAULSON, 2000, p. 88). 
Por exemplo, a classificação de Stammler, a quem se atribui a paternidade de um "jusnaturalismo de conteúdo variável”, como um reducionista cético pode soar estranho aos seus discípulos. E é o que faz Kelsen ao tratar da divisão stammleriana dos métodos de investigação em causal e teleológico, tendo Kelsen chegado à conclusão de que Stammler reduz o método teleológico ao método causal, representando uma forma de reducionismo - as razões dessa polêmica que não interessam diretamente aqui, podem ser lidas em (PAULSON, 2000, p. 90 e ss). ${ }^{1}$

De qualquer forma, o quadro sintético trazido acima é pertinente para situar em geral o contexto do surgimento do pensamento kelseniano. Por combater tanto os naturalistas metafísicos em busca de maior objetividade, como os juristas sociólogos em busca da normatividade e de uma ciência exclusivamente jurídica que tem por objeto somente as normas e não fatos sociais, Kelsen conseguiu desagradar a todos, como bem ressalta Norberto Bobbio, analisando as reações às ideias kelsenianas na Itália:

Nessuno vorrà dubitare che cattolici e marxisti siano in contrasto tra loro. Ma non vi è pure il minimo dubbio che sono entrambi risolutamente anti-kelseniani; e che la reazione contro il Kelsen, qui in Italia, fa egualmente capo agli uni e agli altri, e, piú in generale, a tutti coloro che richiedono maggior contatto dello studioso di diritto positivo, da un lato, con i valori di giustizia a cui il diritto positivo si ispira, e dall'altro, con la realtà sociale su cui si forma. (BOBBIO, 1992, p. 17-18).

A hipótese a ser discutida sobre a gênese do pensamento de Kelsen compreende a postulação de três traços do seu modelo de validade: idealismo, formalismo e empirismo. Uma teoria que tenha um objeto de investigação apreendido exclusivamente pela razão só é possível, na visão de Kelsen, se o conceito de razão for ao mesmo tempo uma razão formal, capaz de aceitar qualquer conteúdo independente de postulações valorativas prévias; uma razão ideal, uma vez que todo o conhecimento é fundamentado na própria razão; uma razão empírica, porque não há conhecimento para além da experiência possível, apesar de fundamentado na razão.

\footnotetext{
Diz-nos, ademais, (PAULSON, Stanley L. Fundamentación crítica de la doctrina de Hans Kelsen. Bogotá: Universidad Externado de Colombia, 2000. p. 104, n. 28. (Série de Teoría Jurídica y filosofia del derecho, n. 17)). a respeito das dificuldades da simplificação do que no quadro é descrito como "tese da separação entre direito e moral": "Robert Alexy observa por consiguiente las ambigüedades que son inherentes a la tesis de la separación - ambigüedades relativas a sustancia y procedimiento, observador y participante, etc. - y llega a 64 diferentes versiones. Aun cuando muchas de ellas, como Alexy concede abiertamente, no encuentren ninguna utilización, este ejercicio es notable con respecto al problema de lo que puede significar una aspiración prima-facie a la totalidade. Ver ALEXY, Robert. On necessary relations between law and morality. Ratio Juris, Georgetown, v. 2, n. 2, p. 167-183, jul. 1989.
} 
Aplicando esses termos à validade das normas, trata-se de um conceito formalista, pois não se pode postular cientificamente e objetivamente que a validade depende de conteúdos que pressupõem valores predeterminados, sendo impossível para Kelsen identificá-los sem postular uma metafísica. O formalismo surge então como uma reação às doutrinas do direito natural, as quais identificavam a validade das normas segundo a conformidade lógica de seus conteúdos com conteúdos de origem racional ou divina, transcendentes, portanto.

A principal crítica de Kelsen nesse ponto foi a falta de cientificidade do método que ele então chamou de estático. Uma concepção estática do direito não separa direito e moral, enquanto Kelsen enxergava uma autonomia do direito em face da moral, uma proeminência valorativa da norma jurídica que, por meio do conceito de validade, permitia enxergar a obrigatoriedade do direito positivo ainda que fosse contrário a uma moral vigente, e independente dela. A visão de que o direito não se modificaria, já que seria eterno e imutável, era insustentável. Primeiro porque se verifica na realidade que o direito se modifica e seus conteúdos não são comuns em todas as ordens jurídicas. Em segundo lugar, porque não haveria critério capaz de definir quais normas são válidas, uma vez que os conteúdos considerados imutáveis segundo a razão diferem entre os próprios jusnaturalistas, ou seja, não há uma moral absoluta.

A validade para Kelsen só pode ser identificada cientificamente como um conceito formal, ou seja, desvinculado de qualquer conteúdo previamente determinado. Para Kelsen, essa é a maior virtude de sua teoria: ter identificado os conceitos elementares do direito, de forma pura, por meio de um método divorciado da política, da sociologia, da axiologia, de modo que todos os seus críticos possam aplicá-la a qualquer Estado e reconhecer nele a juridicidade que a Teoria Pura do Direito descreve com certeza científica. Daí que a afirmação de Bobbio, citada logo acima, seja baseada na mesma constatação feita pelo próprio Kelsen sobre a repercussão da Teoria Pura do Direito:

Os fascistas declaram-na liberalismo democrático, os democratas liberais ou os sociais-democratas consideramna um posto avançado do fascismo. Do lado comunista é desclassificada como ideologia de um estatismo capitalista, do lado capitalista nacionalista é desqualificada, já como bolchevismo crasso, já como anarquismo velado. O seu espírito é - asseguram muitos — aparentado com o da escolástica católica; ao passo que outros crêem reconhecer nela as características distintivas de uma teoria protestante do Estado e do Direito. E não falta também quem a pretenda estigmatizar com a marca de ateísta. Em suma, não há qualquer orientação política de que a Teoria Pura do Direito se não tenha ainda tornado suspeita. Mas isso precisamente demonstra, melhor do que ela própria o poderia fazer, a sua 
pureza. (KELSEN, 1960, p. 9-10, prefácio à primeira ed. 1934). ${ }^{2}$

A constatação de que os diversos ordenamentos não permanecem imutáveis no decurso do tempo, isto é, que os ordenamentos são "dinâmicos" e não "estáticos", reflete o postulado básico de Kelsen: só se pode fazer ciência do direito tendo como objeto o direito positivo. Daí a combinação de seu formalismo metodológico com um empirismo que, como será analisado, reflete o espírito vienense de sua época, resumido numa ideia básica: se é necessário evitar toda metafísica nas ciências, logo é preciso ater-se aos dados empíricos. Não há validade constatável numa ordem transcendente. Se há comandos válidos, heterônomos a toda moral, tais são identificáveis pelas formas lógicas, sempre aplicáveis a um ordenamento concreto e individualizado. As normas são comandos válidos não em virtude da sua conformidade com uma ordem transcendente de valores imutáveis, mas sim porque podem ser descritas como comandos emanados de autoridades competentes, reais, historicamente identificáveis. Assim, Kelsen assume os postulados do positivismo clássico do século XIX, segundo os quais não há direito além do posto pelo Estado, identificando a validade empiricamente, em decorrência dos atos de vontade das autoridades.

Não obstante todas essas considerações, a nota mais importante do pensamento kelseniano para a compreensão exata de seu conceito de validade, como há de ser analisado mais adiante, é o que caracteriza sua teoria como uma proposta a ser justificada pelo idealismo: a norma fundamental. Estando a validade em Kelsen vinculada a um postulado antimetafísico, a fundamentação de uma normatividade não pode estar fora do direito: são válidos aqueles comandos de dever-ser que tem um sentido tornado objetivo por outro comando superior na ordem hierárquica. Mas se uma ordem jurídica se distingue das demais construções normativas, sejam morais e ou religiosas, e se Kelsen pretende justificar uma validade racionalmente sem apelar para a transcendência de valores imutáveis, então há que haver um fundamento ideal de validade. Nesse ponto, Kelsen assume um idealismo transcendental numa não pouco problemática filiação à filosofia de Imanuel Kant. E é exatamente quanto aos fundamentos de sua teoria da validade que Kelsen divergirá também das doutrinas conhecidas como realistas, que tendem à identificação da validade com a realidade da norma, isto é, sua eficácia na sociedade histórica e concreta.

$2 \quad$ As duas edições da (KELSEN, Hans. Teoria pura do direito. Coimbra: Arménio Amado, 1984) são citadas respectivamente como (Kelsen, 1934) e (Kelsen, 1960); Já a obra (KELSEN, Hans. Teoria geral do direito e do Estado. São Paulo: Martins Fontes, 1998) é indicada por (Kelsen, 1945) e, finalmente, sua obra póstuma, (KELSEN, Hans. Teoria geral das normas. Porto Alegre: SAFE, 1986) é indicada por (Kelsen, 1979). 
Um trecho que demonstra a aversão de Kelsen simultaneamente ao realismo jurídico e à metafísica jusnaturalista se lê na Teoria Pura do Direito (1960, p. 40), em que o Autor critica o jusnaturalismo dizendo não ser possível pleitear valores absolutos, independente dos atos de vontade objetivos, com sentido normativo e positivo. Em nota de rodapé, critica o jusfilósofo Alf Ross, dizendo que este confunde ser e dever-ser. Ross, no quadro sintético de Paulson citado acima, representaria, na visão de Kelsen, a união da normatividade aos fatos. Kelsen reúne essas doutrinas em torno da dicotomia entre ser e dever-ser para afirmar que, no fundo, essas teorias jurídicas postulam a confusão entre direito e axiologia, ou entre direito e sociologia, o jusnaturalismo defendendo que valores absolutos transcendentes determinam o que deve-ser e o realismo defendendo que o mundo dos fatos (o comportamento dos tribunais, influenciado por uma ideologia judicial, no caso de Ross) é que determina em última análise a vigência das normas.

A necessidade da distinção entre os mundos do "ser" e do "dever-ser" e os problemas advindos da necessidade de uma relação entre validade e eficácia na obra de Kelsen abrem uma ampla discussão à parte. À guisa de apresentação desse problema, no estrito objetivo de situar preliminarmente o pensamento kelseniano na tradição, é preciso destacar que no que tange especificamente à polêmica com o realismo de Ross, Kelsen sustenta que os mundos do "ser" e do "dever-ser" têm em comum um quid (quê) ao mesmo tempo ser (fato) e deve-ser (norma). Isso que Kelsen chamaria posteriormente de "substrato modalmente indiferente" demonstra como os dois mundos são diversos, podendo apenas prever os mesmos conteúdos:

Assim como na afirmação de que algo é devemos distinguir esse "algo", que é, do "ser" que desse algo é afirmado, também na afirmação de que algo deve ser devemos distinguir o "algo", que deve ser, do dever-ser que desse algo é afirmado. (KELSEN 1960, p. 41, nota).

Esse quid que "é" ou de algum modo "será" se relaciona com o quid que “deve-ser", mas as posições que o quid ocupa não são a mesma coisa e não se confundem. Para Kelsen, o juízo de realidade expressado por uma decisão judicial e fundado numa ideologia judicial ou numa moral particular, ao se efetivar, pertence ao mundo do ser, enquanto um outro tipo de juízo construído mentalmente e constitutivo do valor jurídico (independente de se efetivar) pertence ao mundo do dever-ser (juízo normativo). $\mathrm{O}$ valor, por isso, pode ser tanto uma função emocional da consciência, proveniente de uma vontade individual ou coletiva, fundado numa ordem natural, sócio-ideológica ou costumeira - portanto um valor com sentido meramente subjetivo - como também pode ser uma função de conhecimento, proveniente de uma vontade autorizada que prescreve algo — portanto com sentido objetivo. Este último é o único valor que interessa à teoria pura do direito: um valor que não provém de uma ordem racional ou natural, nem de uma 
ideologia judicial do mundo dos fatos, mas um valor que provém do direito positivo: um valor de dever-ser, que muito ao contrário de ser determinado pela realidade, constitui-a e é cognoscível objetivamente pela ciência.

A separação entre ser e dever-ser, desse modo, vai permitir a exata diferenciação entre uma concepção dualista ou idealista de Kelsen e a concepção dita monista ou realista, que identifica ser e dever-ser. Por outro lado, a concepção de valor jurídico objetivo, ou o que é o mesmo, dizer que o dever-ser jurídico tem uma prevalência em relação a qualquer outro exatamente por ser apreendido na experiência positiva é o ponto que distingue a concepção kelseniana das concepções moralistas do direito.

A razão teórica de Kelsen pressupõe, portanto, um empirismo no conhecimento e um idealismo no fundamento, ambos os setores permeados por um método formal. Sem esses requisitos, a ciência do direito, na visão de Kelsen, ou não é "ciência" por falta de rigor, ou não é "do direito" por misturar elementos estranhos aos dados positivos, estranhos às normas dos Estados modernos.

Assim lançadas as bases do pensamento "clássico" do jurista austríaco, é preciso cuidar inicialmente dos problemas teóricos que Kelsen enfrentou na gênese de sua ideia de normatividade. A partir daí, passa-se à análise da sua solução idealista e, em momento posterior, do necessário apego da Teoria Pura do Direito ao empirismo.

\section{A insuficiência do conceito de validade como conceito plural}

Apresentadas essas notas fundamentais, vê-se que o desenvolvimento de uma investigação de fundamentos sobre a validade envolve as grandes opções epistemológicas da filosofia do direito, ou seja, as intuições básicas acerca dos porquês da ordem normativa. Assim, uma linha de pensamento metafísica se pauta por uma proeminência de conteúdos transcendentes na fundamentação do direito, ou, para ficar no exemplo bastante de Platão, de conteúdos conforme a essência mesma do bom, do justo, do prudente ou do temperante. Já uma linha empirista concebe um conceito de direito orientado por elementos mais alcançáveis pelos sentidos: é direito aquilo que em princípio aparece numa determinada sociedade, devidamente documentado (positivado). Em suma, o problema remete à filosofia clássica e se traduz numa oposição entre positivismo e naturalismo jurídicos e à tradicional polêmica em torno de um conceito de justiça absoluto ou relativo.

A distinção entre direito positivo e direito natural e a caracterização deste último como sendo cientificamente inapreensível são notas centrais da Teoria Pura do Direito e é a partir daí que se visualiza um caminho para compreender o que Kelsen quer dizer quando afirma que o dever-ser jurídico existe independentemente de uma correspondência a uma ordem transcendente: 
Exatamente como a conduta efetiva dos indivíduos pode ou não corresponder às normas do Direito positivo que regula esta conduta, o Direito positivo pode ou não corresponder a um Direito ideal, apresentado como justiça ou Direito "natural". É na sua relação com o direito ideal (...) que surge a realidade do Direito positivo. A sua existência é independente da sua conformidade ou não conformidade com a justiça ou o Direito "natural". (KELSEN, 1945, p. xxxix, prefácio).

Desse modo, a distinção de um conceito de dever-ser jurídico de outros tipos possíveis de dever-ser, por exemplo, o dever-ser moral, é uma decorrência de um postulado epistemológico primeiro que aponta para uma noção mais formal de validade. Seja o que for esse conceito, ele permite dizer que há uma ordem normativa peculiar que "vale" mais que outras: a ordem jurídica presente e localizada no tempo e no espaço. Numa primeira análise, portanto, a ideia aproximada do que seja a validade normativa implica uma distinção a que Kelsen recorre como pressuposta, uma visão de mundo prévia que define o modo de descrever a realidade. Trata-se de uma opção prévia que o Autor (como todos nós) fez ao preferir investigar o direito segundo uma concepção positivista, empirista, como condição para ser científica.

Verifica-se, ademais, que a validade é um conceito relativo porque associado à ideia de valor. Um valor só faz sentido numa relação entre dois entes, no mínimo, pois não é possível ao senso comum identificar o que seja o belo, o justo e o bom por si só. Se um homem é bom, ele o é apenas na medida em que outros são "menos bons" que ele. Diante de um outro homem admirado por suas virtudes, dir-se-á que esse homem é "tão bom quanto" o outro. E perante um mestre, um santo, ou Deus, dir-se-á que aquele mesmo homem é ruim, já que "não tão bom quanto" o outro. De qualquer modo, o valor sempre se põe numa relação. Assim, a validade, enquanto valor atribuído a comandos de dever-ser, é relativo na medida em que distingue, privilegia ou pretere um comando em relação a outro. Além disso, como será melhor delineado na análise da norma fundamental, a validade é um conceito que, além de estabelecer uma relação valorativa, é ainda relacional num outro sentido: só se compreende a validade numa relação entre normas. Para os naturalistas, um comando tem validade porque existe em relação a um valor absoluto. Para um realista, tem validade o comando que estiver em relação com uma prática social (ou judicial). Para Kelsen, a validade é identificada como uma relação entre normas positivas. Só há validade porque uma norma assim determina:

Los criterios de identificación establecen qué requisitos debe reunir un enunciado de derecho para que sea válido. La noción de validez es, por lo tanto, relativa a un criterio o un conjunto de criterios de identificación. (ALCHOURRÓN; BULYGIN, 1998, p. 118-119). 
A ideia de validade, à parte suas eventuais relações com uma ideia de justiça, parece ser o ponto chave de uma ideia de direito, isto é, a atribuição de um privilégio valorativo (ou de uma preterição valorativa) a uma classe de comandos em relação a outros - para Kelsen, por exemplo, um privilégio de deveres oriundos de um contrato em relação a deveres morais ou religiosos.

O intuitivo nessa argumentação é que a ideia de validade parece remeter a problemas filosóficos mais profundos, como, por exemplo, saber o núcleo central da pergunta “por que deve-ser?", referente em última análise ao problema da justiça, expresso na pergunta “deve-ser aquilo que é justo?”. Como não se pretende aqui avançar por essa seara, o encaminhamento do conceito de validade à luz da epistemologia servirá apenas para introduzir o conceito de validade segundo a visão de Kelsen como um empirista: a explicação da validade se dá em função das ordens jurídicas positivas, postas, históricas e, nesse sentido, experimentadas. "Por que deve-ser?” Kelsen responderá: "porque foi assim dito pelo Estado".

Nesse ponto, nas obras de Kelsen fica evidente que suas teses sobre a validade excluem a histórica preocupação com a justiça, tema que preferiu tratar em separado, sem abandonar, mesmo nessa seara filosófica, seu conhecido relativismo. Como resultado desse corte epistemológico, o problema de fundo filosófico relacionado com a validade deixa de ser a justiça para ser a legitimidade. Às questões como "por que deveser?" ou "por que o direito obriga mais que a moral?" Kelsen responderá não "porque as ordens jurídicas são justas", mas sim “porque as ordens são válidas”. Essa é uma questão filosófica de base para Kelsen, a partir da qual se enraíza seu formalismo, cerne das críticas mais ferrenhas por parte daqueles que não conseguiam ver o jurídico separado da justiça.

Então, torna-se necessário identificar algumas ideias relacionadas ao conceito de validade para proceder à delimitação exata do termo na concepção de Kelsen e compreender melhor seu formalismo. Para tanto, as considerações de Carlos Santiago Nino (1985 e 1998) são fundamentais, já que esse Autor aprecia com detalhes esse conceito na obra de Kelsen.

Com base nas considerações de Santiago Nino, em virtude da dificuldade de conceituação exata, ao menos em princípio, pode-se organizar metodologicamente o raciocínio segundo uma ordem do que a validade pode ser (critérios positivos) - caso em que se parte do pressuposto de que ainda não se sabe o que ela é - e do que a validade não pode ser (critérios negativos) - o que é mais fácil afirmar com maior grau de certeza, com um juízo definitivo do que certamente a validade não é para Kelsen, isto é, aquelas notas que não são exclusivas de sistemas jurídicos válidos.

Primeiramente, o que a validade pode ser, ou seja, suas características mais marcantes (critérios positivos): 
1) Força vinculante: sendo uma espécie de privilégio de sentido em relação a outros comandos (da moral, por exemplo), a validade é uma característica da vinculação a deveres (jurídicos) em detrimento de outros (morais).

2) Normatividade (dever-ser): validade como normativo não quer dizer exatamente que o que "vale" "deve-ser", pois pode haver um dever-ser que não seja válido (dever-ser subjetivo ou, no máximo, um dever-ser objetivo de outro sistema, como o da religião, da moral, dos costumes), mas sim quer dizer basicamente que a validade está no mundo dos sentidos intelectivos em oposição a qualquer consideração do mundo do ser: é válido aquilo que deve-ser segundo um sentido peculiar, ideal, independentemente do "ser" do mundo fático.

3) Existência do próprio dever-ser: se a norma é válida porque se lhe atribui um sentido, que então passa a ser descrito como sendo objetivo, esse sentido objetivo, por definição, passa a ser dito existente. Sendo assim, o comando válido tem esse sentido privilegiado de dever-ser, objetivo, e portanto existe como norma; o comando que não o tem não existe juridicamente.

4) Pertinência a (relação com) um conjunto de outras normas válidas globalmente eficaz: validade significa participar de um conjunto de normas com sentido real, existente no mundo em que vivemos. Uma norma que pertence a um sistema válido é por sua vez válida, mas isso não se aplica aos sistemas imaginários, do direito natural, do direito divino etc. Isso significa que não há norma jurídica válida sozinha e que a validade geral do conjunto normativo tem outras referências (empíricas) que sustentam o conceito normativo.

negativos):

E o que a validade não é ou não é suficiente para caracterizá-la (critérios

1) Validade não é decorrência de uma simples derivação entre comandos, pois um comando de um gângster também deriva da ordem do chefe da máfia e não é válido por isso. A simples relação entre dois comandos não quer dizer que dela surja uma proeminência valorativa.

2) Validade não é pertinência a um sistema logicamente consistente: a ordem de um ladrão pode pertencer a um sistema moral antijurídico, mas não menos consistente que o sistema jurídico. $\mathrm{O}$ que se pode dizer, como acima, é que se um comando de dever-ser pertence a um sistema válido, então é válido. Mas a simples pertinência a um sistema de comandos com consistência entre si não quer dizer que daí surja 
uma proeminência valorativa. Validade não decorre de relações de conteúdos sem contradições: uma ordem de ideias sem contradições pode valer, mas não vale mais que outra só pela sua consistência. Assim, um sistema jurídico com inconsistências lógicas em seus valores adotados pode ser válido, enquanto um outro sistema, por exemplo, da moral, totalmente consistente, pode não ser. A respeito, sugere Santiago Nino: "los juristas pueden presentar el sistema jurídico como un todo consistente $\mathrm{y}$, al mismo tiempo, urgir a los jueces a no aplicarlo" (1998, p. 23).

3) Validade não decorre de um contexto empírico: Kelsen afirma que a validade é um juízo do mundo dos sentidos, ideal, que não deriva simplesmente de uma relação direta com as práticas sociais. Assim, pode haver contextos diversos, segundo os quais uma norma é adequada ou não, mas ela será válida em todos eles.

Desses "critérios negativos", cumpre notar apenas que, numa análise mais cuidadosa, intui-se terem também eles alguma relação com o conceito de validade. Assim, apesar de derivação, consistência e contexto não serem determinantes, os comandos de dever-ser válidos costumam apresentar essas características, ainda que não sejam exclusivas das normas ou ordens jurídicas. Assim, é possível afirmar que uma norma válida também deriva de uma outra norma válida; que ela pode pertencer a um sistema de normas consistente; ou que ela reflete um contexto social. Estas duas últimas características são inegavelmente importantes para a validade, de modo que, se não dão origem à validade, podem dar causa a sua perda, influenciando - ainda que negativamente - as normas através do requisito de "mínimo de eficácia". Esse é um dos pontos mais difíceis da proposta da Teoria Pura, pois envolve a questão da eficácia social da norma válida, que só pode ser compreendido com os fundamentos kantianos que Kelsen assume.

Atentando aos critérios positivos, surge agora a questão: esses critérios são suficientes? Inicialmente, identifica-se o conceito de validade em Kelsen como força vinculante, existência, pertinência a um sistema e como normatividade, critérios estes que não são isolados, mas correlatos entre si. Então uma solução seria tratar dessas possíveis definições não como características exclusivas, mas como elementos dependentes entre si, que apontam inseparavelmente para um conceito de validade plural. O problema é que esses elementos podem ser explicados um referindo-se ao outro, e até mesmo em ordem aleatória:

Força vinculante: sinônimo de obrigatoriedade. A norma tem força vinculante porque um indivíduo está obrigado a se comportar segundo seu conteúdo. Há então uma obrigatoriedade determinada por algo... O que é esse algo? Existência: a obrigatoriedade de uma norma se explica pela sua existência. Então um indivíduo está 
obrigado a agir conforme a norma porque a norma existe. A existência é determinada por algo... O que é esse algo? Normatividade: a norma existe porque tem um sentido objetivo, ou seja, o comando de dever-ser tem um sentido objetivo que o destaca de um mero comando subjetivo, que por sua vez é dado no intelecto, idealmente: é um sentido normativo. Esse sentido objetivo é determinado por algo... o que? Pertinência a um sistema: um comando de dever-ser tem sentido objetivo porque pertence a uma ordem escalonada com sentido objetivo, isto é, uma ordem globalmente eficaz. No entanto, surge a seguinte dificuldade ao teórico: se um comando é válido porque pertence a um sistema válido, por que esse sistema é válido? Isso remete a uma outra ordem de ideias, sobre a validade do sistema. Esse sistema é válido em virtude de algo... o que? Força vinculante: um sistema é descrito como válido porque seus comandos têm o caráter de normas vinculantes. Etc.

Como se vê, esses conceitos, se forem explicados numa circularidade, como autoreferentes, podem ser ilusórios e a compreensão resta insatisfatória, ao menos do ponto de vista científico e rigoroso que Kelsen propõe. Um exemplo de Santiago Nino ilustra essa dependência recíproca entre as ideias de validade e sua aleatoriedade, ligandoas dessa vez em outra ordem:

Así, se podría sostener que la validez de una norma es equivalente a su existencia, pero que una norma jurídica existe no cuando tiene fuerza obligatoria moral, sino cuando pertenece a un orden jurídico que tenga vigencia y que una norma pertenece a un orden jurídico cuando su sanción está autorizada por otras normas del sistema. (NINO, 1998, p. 134 - grifo nosso).

Deve haver um critério último, delimitador, que fundamente a todos e a cada um desses elementos do conceito de validade que se referem entre si. O que daria sentido a todas essas notas correlatas do conceito é explicado pelo que se define como pressuposição da validade. Nesse ponto, o último critério positivo enumerado, o da pertinência a um sistema, tem também sua importância destacada na teoria pura do direito, pois se trata de uma nota do conceito de validade com proeminência epistemológica. A pertinência a um sistema significa, em última análise, a submissão de todos os elementos correlatos a um sentido normativo básico que é, no pensamento clássico de Kelsen, pressuposto. Um comando de dever-ser tem normatividade, existe, tem força vinculante, bem como o sistema a que pertence é válido em virtude da pressuposição de validade. A validade, então, se necessário descrevê-la num conceito, redunda nessa pressuposição mais que de qualquer outra nota característica, sendo, portanto, necessário tratar do argumento transcendental para se compreender o conceito de direito em Kelsen. 
3. A gênese do argumento transcendental

A Teoria Pura do Direito nasceu em 1911 com uma grande obra de Kelsen denominada Hauptprobleme der Staatsrechtslehre (Tübingen, 1911). ${ }^{3}$ Nessa obra, Kelsen expõe os fundamentos de como compreende a distinção entre ser e dever-ser, afirmando que uma teoria do direito só tem sentido se o material for estudado como pertinente ao mundo dos sentidos intelectivos, que é o mundo da cultura, do dever-ser. Essa nota característica passou a ser definida como uma filiação de Kelsen à filosofia neokantiana.

A filiação de Kelsen ao neokantismo é descrita por Stanley Paulson como sendo uma decorrência do seu posicionamento contrário a algumas considerações de Gerber e de Jellinek, que, na teoria do Estado, admitiam a possibilidade de que o mesmo objeto de estudo fosse descrito por diferentes métodos, em especial o método descritivo sobre as realidades naturais do Estado e o método normativo que trata das relações intelectivas que se operam na mente dos juristas.

Kelsen, que se comprometió como sus predecesores con la pureza metódica, no quiere tener nada que ver con esa idea de que uno y el mismo objeto puede ser asunto de diferentes métodos, y su crítica a la "teoría de las dos caras" de Jellinek parece ser implacable: si por hipótesis existen dos métodos, entonces hay también dos distintos asuntos u objetos, pues la identidad del objeto de conocimiento está condicionada por el método del conocimiento. (PAULSON, 2000, p. 34).

Nessa linha de argumentação, Kelsen apresenta as linhas básicas da tese que seguiria até o fim da vida: o Estado, tradicionalmente descrito como um objeto pertencente à realidade social e empírica, causalmente determinada, é a outra face do Direito, podendo ser perfeitamente descrito como um objeto normativo, próprio do método que vê uma dada realidade como "dever-ser".

O modo como essa realidade causal passa a ser descrita como normatividade é por meio do conceito chave de imputação. Na primeira edição da Teoria Pura do Direito Kelsen já formulava o argumento transcendental e notoriamente associava a "categoria do dever-ser" ao nexo de imputação (1934, p. 49-50). Suas formulações posteriores do argumento igualmente não escondem o desejo de determinar a oposição entre ser e deverser, no seu entender, como evidente:

O problema do Estado é um problema de imputação. O Estado é, por assim dizer, um ponto comum no qual se projetam ações humanas, um ponto comum de imputação

Título com tradução aproximada para Problemas Fundamentais da Teoria do Direito Público (para alguns, Problemas Fundamentais da Teoria do Direito e do Estado). 
de diferentes ações humanas. Os indivíduos cujas ações são consideradas atos do Estado, cujas ações são imputadas ao Estado, são designados "órgãos" do Estado. (...) Qual o critério dessa imputação? Eis a questão decisiva que conduz à essência do Estado. Uma análise demonstra que imputamos uma ação humana ao Estado apenas quando a ação humana em questão corresponde, de uma maneira específica, à ordem jurídica pressuposta. (...) O resultado de nossa análise é o de que não existe um conceito sociológico de Estado diferente do conceito de ordem jurídica; e isso significa que podemos descrever a realidade social sem usar o termo "Estado". (KELSEN, 1945, p. 277).

O ponto de imputação é a referência do conceito normativo de Kelsen, já que a partir dele se tem o sentido de dever-ser a par - e em certo sentido até mesmo em detrimento - do que, no mundo do ser, é descrito como relação de causalidade. No entanto, surge uma questão fundamental para o desenvolvimento desse raciocínio: se tudo o que pertence ao mundo do direito deve isso ao ponto de imputação, por que esse ponto é ele mesmo direito? Até aqui, em seus Hauptprobleme (inclusive em sua $2^{\mathrm{a}}$ edição, de 1923), Kelsen tem de simplesmente sustentar que o direito se autopressupõe. No dizer de Paulson:

\begin{abstract}
Si la noción del orden jurídico como punto de referencia definitivo significa que el orden jurídico tiene que suponerse a sí mismo, con ello entonces - lejos de suministrar un fundamento independiente para la validez de las "construcciones puras" de Kelsen - no se da respuesta al problema acerca del fundamento de esas construcciones, sino que se plantea nuevamente. Kelsen volvió en verdad sobre este problema, y sus esfuerzos por responderlo de manera adecuada marcaron sus posteriores intentos de plantear su doctrina del derecho sobre una nueva base. (PAULSON, 2000, p. 62).
\end{abstract}

Eis aqui o ponto de partida para a busca de Kelsen por mais fundamentos transcendentais de sua teoria. A imputação dá sentido normativo às relações sociais, mas sua própria juridicidade fica sem explicação. É então que Kelsen se vê diante da necessidade de apresentar seu conceito de norma fundamental.

A justificativa é simples: se os fundamentos do direito não podem estar na "faticidade" por fidelidade ao dever-ser, assim como não podem estar na moral, por fidelidade ao rigor científico, então, na visão de Kelsen, a única alternativa é utilizar a via dos apriorismos:

Con la teoría de la norma fundamental, la Teoría pura del Derecho sólo intenta poner al descubierto, mediante un análisis del proceder efectivo, las condiciones lógico- 
trascendentales del método de conocimiento positivo del Derecho que se practica desde tiempos inmemoriales. (KELSEN, 1934, p. 100, ítem 29).

Compreendida a necessidade lógica dos conceitos transcendentais, sem os quais todo o sistema ficaria sem explicação, passa-se a uma análise dos vínculos de Kelsen com as filosofias kantiana e neokantiana em busca de uma melhor compreensão de seu conceito de validade.

\section{Os fundamentos do conhecimento jurídico em Kant}

Uma das hipóteses iniciais para a compreensão do conceito de validade em Kelsen torna imprescindível uma análise mais detalhada sobre os caminhos que o Autor seguiu na estruturação de sua tese transcendental. Se o argumento é sustentável ou não, é isso o que vai permitir um juízo adequado sobre as críticas que a Teoria Pura do Direito sofreu no curso do século XX. A busca de seus fundamentos remete inicialmente à análise do pensamento idealista de Immanuel Kant, cuja obra fora analisada ainda na juventude por Kelsen. Essa identificação é rodeada de problemas, já que a farta doutrina sobre o kantismo em Kelsen não permite um entendimento uníssono. Vejamos como se dá essa associação entre o jurista e o filósofo.

Kant foi o primeiro pensador a identificar formas imutáveis no pensamento como passo indispensável ao conhecimento seguro. Em sua teoria do conhecimento, seguiu o rastro de René Descartes, que inaugurara a preocupação filosófica com o entendimento, a preocupação com o próprio eu pensante já um século antes. A descoberta do cogito $^{4}$ passou a ser ponto de partida irrefutável para o conhecimento. Atento à importância do sujeito no conhecimento identificada por Descartes, Kant realizou o que é comumente descrito como "revolução copernicana" na filosofia. O centro da investigação filosófica passou do objeto para o sujeito pensante, com a identificação da consciência subjetiva como função indispensável ao conhecimento:

Como Copérnico, que não podendo explicar os movimentos celestes com a suposição de que todo o exército dos astros gira em redor do espectador, o conseguiu explicar melhor supondo que o observador gira sobre si mesmo, do mesmo modo, Kant, em vez de admitir que a experiência humana se modela sobre os objetos, em cujo caso a sua validade seria impossível, supõe que os próprios objetos enquanto

4 "Cogito, ergo sum" - "Penso, logo existo" - é a frase que sintetiza a ideia cartesiana de que o conhecimento, seja qual for o sujeito, baseia-se no princípio metodológico de que o sujeito pensa. O conhecimento de que "eu penso" é identificado como ponto elementar primeiro e irredutível a partir do qual se inicia qualquer investigação cognoscitiva com pretensões objetivas. 
fenômenos se modelam sobre as condições transcendentais da experiência. (ABBAGNANO (VIII), 1995, p. 64, § 516).

Esse enfoque foi o criticismo de Kant, que se voltou propriamente aos fundamentos da atividade pensante do sujeito, identificando, especialmente em sua obra Crítica da Razão Pura, aquelas que seriam as estruturas fundamentais do pensamento humano. Essas estruturas ou formas imutáveis eram, na ontologia clássica, relacionadas exclusivamente aos objetos, que estariam fora do sujeito pensante (assim ocorre, por exemplo, nas filosofias de Platão e Aristóteles). Segundo Kant elas foram identificadas no próprio entendimento humano, já que para ele o objeto se organiza mentalmente e isso só é possível por intermédio de categorias fundamentais do entendimento puro. Essas formas transcendentais estão no sujeito, que, por meio da razão pura, pode organizar e constituir o conhecimento. Assim, as categorias se aplicam à realidade empírica caótica (a natureza) apreendida através dos sentidos e possibilitam a identificação do conhecimento como o surgimento do fenômeno. Tudo o que é possível ao sujeito conhecer; portanto, é uma síntese criadora entre forma e matéria, isto é, as categorias aplicadas às sensações.

Ora, experimentar não é, simplesmente, receber, mas, antes de tudo, para Kant, é constituir o dado recebido como objeto do conhecimento. Isto significa que aquilo que, na linguagem comum, chamamos nossa experiência do mundo, já é, sempre, mediada por uma atividade prévia do sujeito, através da qual todo e qualquer dado é transformado em objeto para o homem, isto é, através de um processo, que contém diferentes momentos: em primeiro lugar, o material da intuição humana é ordenado no espaço e no tempo, que são as formas aprióricas da sensibilidade humana. Tal material, já de certo modo unificado pela sensibilidade, atinge o status de objeto na medida em que é referido a uma unidade última, a unidade da consciência, do "eu penso". Esta unidade é a instância de constituição da objetividade, uma vez que é ela que constrói a unificação dos dados e sem unificação não há, propriamente, conhecimento. Neste sentido, o específico do entendimento humano é, precisamente, a organização da experiência humana de acordo com regras cuja validade é anterior à própria experiência, porque sua condição de possibilidade. (OLIVEIRA, 1980, p. 9).

A busca de estruturas imutáveis que pudessem trazer certeza ao homem, tal como desejou Kant, não poderia, no entanto, assegurar um conhecimento fenomênico seguro e imutável para sempre, pois estando a imutabilidade apenas nas formas de organização do entendimento e de aplicação das categorias ao dado empírico, que é sempre fugaz e mutável, apreender-se-ia um fenômeno igualmente mutável e contingente. Assim, apenas as categorias são um conhecimento necessário e imutável, por isso chamado de conhecimento a priori ou transcendental. 
Enquanto a tradição filosófica afirmara ter encontrado a essência das coisas no pensamento, como disseram Platão e Descartes, ou, ao invés, que o conhecimento assentava-se na experiência, como postularam as doutrinas empiristas de Francis Bacon, David Hume e John Locke, Kant, por outro lado, buscava uma estrutura do pensamento tão pura e necessária que fosse comum a todo ser racional a possibilidade de atingir um conhecimento seguro desde que se seguissem os princípios inafastáveis da razão. O conhecimento dos fenômenos, segundo Kant, não estaria baseado só nos dados empíricos e tampouco só no entendimento, mas numa síntese que representa a aplicação das formas intelectivas da razão transcendental às experiências da natureza. E, ao fazer isso, Kant tentava dar um estatuto científico à metafísica tradicional, mas já com outro enfoque, pois não pretendia afirmar ter encontrado qualquer espécie de conhecimento dos "objetos em si" ou das "essências", mas apenas das condições de possibilidade do conhecimento fenomênico.

Kant desejava afastar-se do ceticismo empirista, que afirmava a impossibilidade de qualquer estrutura cognitiva estável em face da experiência sensorial e, ao mesmo tempo, evitar o dogmatismo idealista, que admitia ter encontrado as próprias essências com o puro raciocínio dialético ou analítico, tal como se apresentara de modo marcante a concepção platônica da verdade situada no "mundo das ideias". Kant partiu então da postura natural do homem de investigar o que está por trás dos fenômenos - já que o homem é um animal metaphysicum — buscando os fundamentos desse conhecimento. Mas lendo o radicalismo empirista de David Hume, Kant pareceu ter chegado ao limite do conflito entre metafísica tradicional, que supunha estarem as propriedades do conhecimento no próprio objeto, e o ceticismo dos empiristas, que enfatizava uma dúvida, no sujeito, sobre a real cognição de uma substância segura e definitivamente estável no mundo que pensamos. Diante desse impasse, Kant declarou que a leitura de Hume o despertou de um sono dogmático, já que ele mesmo professava, até aquele momento, uma metafísica ainda tradicional. Era preciso fundamentar o conhecimento em uma outra via segura, uma alternativa filosófica à oposição entre racionalismo e empirismo da tradição filosófica. Essa proposta admitiria a mutabilidade dos fenômenos e, ao mesmo tempo, alguma segurança inatacável fornecida pela razão humana.

Desse modo, formulou uma profunda crítica à metafísica tradicional, que pretendia atingir o "ser em si" (ou "coisa em si") por meio de uma razão pura, independentemente da experiência. Esse tipo de metafísica surgiria da aplicação da razão sobre o vazio, o que era inadmissível para Kant tendo em vista que o conhecimento só seria possível mediante uma síntese entre formas puras do entendimento e os dados sensíveis. E se não há vazio cognoscitivo, por outro lado não há uma essência nos moldes tradicionais, 
como algo imutável, transcendente, externo à consciência e independente da experiência, de modo que Kant estava ciente dos limites formais de seu criticismo. ${ }^{5}$

Identificadas as linhas gerais da filosofia teórica de Kant, já se pode visualizar como a obra de Kelsen pretendeu exercer papel semelhante no específico campo do direito. É possível afirmar que assim como a Crítica da Razão Pura descreve as condições de possibilidade inafastáveis, o fundamento racional último e o modo de obter o conhecimento das ciências naturais, a Teoria Pura do Direito descreve as condições de possibilidade, o fundamento racional e o modo de conhecer o objeto da ciência ou dogmática jurídica. Kelsen, assim como Kant, desenvolve simultaneamente uma lógica formal e uma lógica transcendental (que também é formal na medida em que trata apenas da possibilidade e do fundamento do conhecimento). A lógica formal trata da correção do raciocínio já formado; a lógica transcendental, da possibilidade da própria formação do raciocínio.

Desse modo, enquanto uma "lógica jurídica transcendental"' está voltada para o conhecimento a priori do direito, para aquilo que lhe é próprio segundo uma teoria pura e mesmo para a possibilidade e a fundamentação do conhecimento jurídico, uma "lógica jurídica formal" está sempre ligada a um conhecimento aplicado, da possibilidade de o conhecimento ser válido formalmente, e verdadeiro ou falso em vista da experiência. Na esfera transcendental, nota-se que Kant e Kelsen, cada qual em seu campo particular de investigação filosófica, elaboraram suas teorias buscando as condições de possibilidade do conhecimento científico, com a intenção de prescindir de qualquer conteúdo cognoscível para isolar assim as categorias puras da racionalidade e deixar o preenchimento com conteúdos determinados a cargo das teorias especiais: por exemplo, a física, no campo da ciência natural, e a dogmática jurídica, no campo da ciência do direito.

\begin{abstract}
Así como Kant en su Filosofía trascendental se proponía investigar las condiciones de posibilidad de la ciencia física, dejando a esta ultima el estudio experimental de los fenómenos y el establecimiento de leyes, de parecida manera Kelsen se propone el estudio de las condiciones formales (¿categoriales?) del conocimiento jurídico, dejando a la dogmática el estudio particular de los ordenamientos jurídicos concretos.
\end{abstract}

Es claro que el intento kelseniano de establecer los principios a priori, que sean las condiciones de posibilidad, universales y formales del conocimiento jurídico, viene a constituir

\footnotetext{
5 Kant, todavia, admite a “coisa em si” como algo que está por trás dos fenômenos, algo que pode ser pensado mas não conhecido ou afirmado pelas forças da razão pura.

6 O uso da expressão "lógica jurídica" é aqui utilizado entre aspas com a intenção de ressalvar que o próprio Kelsen não admitiria essa terminologia, aqui necessária para efetuar algumas distinções.
} 
una especie de construcción trascendental que unifica e constituye dicho conocimiento en cuanto conocimiento jurídico. (AYALA, 1974, p. 31-32 - similarmente, EBENSTEIN, 1947, p. 31).

Nesse sentido, enquanto a obra de Kant permite passar do conhecimento filosófico para o conhecimento das ciências particulares sem, todavia, afirmar algum conhecimento imutável acerca dos objetos dessas ciências, a obra de Kelsen permite partir do conhecimento puro do Direito para o conhecimento dos direitos positivos particulares de cada nação, sem postular qualquer conteúdo imutável ou qualquer conhecimento prévio acerca do que deve-ser objeto de um determinado complexo de normas. Daí porque Kelsen afirme que sua Teoria Pura do Direito pretendeu descobrir como o direito é e não como o direito deveria-ser. (cf. KELSEN, 1960, p. 17).

Na Crítica da Razão Pura, esse conhecimento puro — ou formal — são as intuições puras da sensibilidade (espaço e tempo) e os conceitos puros do entendimento (as categorias kantianas, a exemplo da unidade, realidade, causalidade, necessidade). São estruturas do pensamento que, por serem necessárias e independentes da experiência, permitem identificar o fundamento último do conhecimento na própria racionalidade, uma vez que são pressupostos transcendentais aprioristicamente identificados em todo e qualquer sujeito. Na Teoria Pura do Direito, similarmente, vê-se que as condições de possibilidade do conhecimento do direito - ou conhecimento formal do direito — são estruturas básicas que Kelsen identificou como condições irredutíveis e inafastáveis de qualquer pensamento que toma ciência de uma normatividade, a partir de um ordenamento jurídico dado na realidade. Essas condições, segundo se pretende demonstrar, seriam a imputação e a norma fundamental.

Desse modo, ainda que Kelsen não tenha escrito sua obra básica à luz da terminologia kantiana e haja algumas diferenças teóricas que serão detalhadas, é possível verificar que, se essas estruturas do direito são identificadas pelos sujeitos que pensam acerca de todo e qualquer Estado, então elas são dadas a priori na compreensão do jurídico: os fundamentos do conhecimento do direito seriam a norma fundamental e a imputação, categorias pressupostas na própria razão e indispensáveis para que se opere a identificação da validade entre as normas de uma ordem jurídica. Isso Kelsen afirma textualmente:

Mas também sob este aspecto, existe analogia com a lógica transcendental de KANT. Assim como os pressupostos lógico-transcendentais do conhecimento da realidade natural não determinam por forma alguma o conteúdo das leis naturais, assim também a norma fundamental não pode determinar o conteúdo das normas jurídicas ou das proposições jurídicas que descrevem as normas jurídicas. Assim como só podemos obter o conteúdo das leis naturais 
a partir da experiência, assim também só podemos obter o conteúdo das proposições jurídicas a partir do Direito positivo. A norma fundamental tão-pouco prescreve ao Direito positivo um determinado conteúdo, tal como os pressupostos lógico-transcendentais da experiência não prescrevem um conteúdo a esta experiência. Aí reside precisamente a diferença entre a lógica transcendental de KANT e a especulação metafísica por ele rejeitada, entre a Teoria Pura do Direito e uma teoria metafísica do Direito do tipo da doutrina do Direito natural. (KELSEN, 1960, p. 283).

Essa consideração é fundada na separação que Kant julgava essencial entre o mundo da necessidade, dos fatos, das causas (em alemão, sein) e o mundo da moral (em alemão, sollen). O ponto de partida para suas considerações sobre a moral e sobre a possibilidade de uma razão prática é exatamente o problema central da indeterminação do agir - que deve ser contornado para que uma razão prática seja possível. De todo modo, há uma separação entre os dois mundos de modo que, em princípio, os deveres não mantêm relação com os fatos:

Com efeito, relativamente à natureza a experiência fornecenos a regra e é a fonte da verdade; porém, no que concerne às leis morais, a experiência é (infelizmente) a mãe da ilusão; e é sumamente reprovável tirar as leis sobre o que devo fazer daquilo que é feito ou querer limitar a primeira coisa pela segunda. (KANT, 1999, p. 243).

Kelsen não deixou de manifestar essa mesma ideia por várias vezes, desde o princípio, firmando a ideia de que o dever-ser como categoria é o que possibilita toda a visão normativa:

A contraposición de ser y deber ser es lógico-formal, y
mientras nos mantengamos en el terreno lógico-formal es
imposible tender un puente entre esos dos mundos separados
como están por un abismo infranqueable. (KELSEN,
Hauptprobleme der Staatsrechtslehre, Tübingen, 1911,
apud PAULSON, 2000, p. 39).

Em outras palavras, o modo como se constitui o conhecimento normativo e pelo qual se atribui validade de uma norma a outra é a atribuição de um sentido objetivo categorial de "dever-ser" a um ato da vida social, segundo um encadeamento lógico, que é tornado formalmente válido em virtude da transcendentalidade/necessidade de uma norma fundamental, o que impede um regresso ao infinito na busca de um fundamento. Kelsen, assim, pretendia assegurar que a autonomia da validade das normas jurídicas em relação à moral e aos fatos sociais provém desses dois pressupostos lógico-transcendentais kantiano, ora aplicados a uma crítica da razão jurídica. 
Portanto, a norma fundamental e a imputação aparecem como fundamento do conhecimento formal do direito e ao mesmo tempo uma condição necessária da racionalidade jurídica na constituição do conhecimento do direito. Qualquer que seja a nação, qualquer que seja o sujeito que opere o direito ou que pretenda descrevê-lo, esse sujeito terá como elementos necessários para a compreensão da ordem estatal como ordem jurídica uma norma fundamental pressuposta e a categoria da imputação, que permitam fundamentar, organizar e conhecer o "dever-ser" jurídico. O próprio Kelsen é explícito sobre a natureza a priori da norma fundamental:

Uma carta de Kelsen endereçada a Renato Treves a 3 de
agosto de 1933 nos ajuda a compreender o estado de ânimo
que conduziu a elaboração da teoria pura do direito: eu
administro, escreve Kelsen, "o mais fielmente possível a
herança espiritual de Kant"; reconhece ainda "ir além do
pensamento de Kant", revelando a Grundnorm (norma
fundamental) não como produto de normatividade mas
como o índice da capacidade a priori que tem a razão
de unir sinteticamente, em toda norma jurídica, (...) a
positividade e a normatividade. (GOYARD-FABRE, 1993,
p. 6, Prefazione, tradução própria).

Diante dessas semelhanças, é possível afirmar que alguns princípios inspiradores da obra de Kelsen provêm do espírito kantiano de identificar no mundo intelectual estruturas a priori imutáveis e necessárias que permitam atingir um conhecimento a posteriori, ainda que os conceitos de norma fundamental e de imputação sejam objeto de controvérsias. Dito isso, é necessário observar que a classificação de Kelsen como um pensador kantiano não é aceita sem ressalvas. As divergências se iniciam pelo conceito de imputação comparado com o de causalidade, passam pela capacidade ordenadora da razão, que não seria passiva, mas constitutiva dos fenômenos cognoscíveis e também pela possibilidade de uma razão prática em harmonia com a própria tese kantiana da separação entre ser (campo teórico) e dever-ser (campo prático).

No que tange especificamente ao princípio de causalidade, surge uma dúvida conceitual apta a por em dúvida se Kelsen seria, rigorosamente, kantiano.

A polêmica se dá nesse ponto quanto ao princípio de causalidade, para Kant extensivel à qualidade de categoria a priori e inafastável, e para Kelsen um princípio pertencente ao entendimento, mas não desde sempre ou a priori. Textualmente, a categoria da causalidade - que para Kant é a-histórica, eterna, imutável e a priori-é denominada por Kelsen um princípio:

A conduta dos indivíduos, tal como ela é efetivamente, é determinada por leis da natureza de acordo com o princípio de causalidade. Isto é uma realidade natural. (KELSEN, 1945, p. XXIX, prefácio). 
Kelsen nega a causalidade como categoria do entendimento, uma vez que, para ele, é um princípio situado historicamente, ausente no pensamento do homem primitivo e, portanto, não esteve sempre e inexoravelmente presente no entendimento humano:

La causalidad no es, como se ha pensado, una forma mental dada con necesidad natural a la conciencia humana, un concepto innato del entendimiento, sino que hay períodos en la historia del espíritu humano en que todavía no se pensaba causalmente, es decir, en que no se tenía conciencia todavía de la causalidad como una ley absolutamente válida de todo acontecer. (KELSEN. "La aparición de la ley de causalidad a partir del principio de retribución". La Idea del Derecho Natural y Otros Ensayos. Buenos Aires: Editorial Losada, 1946, p. 56; apud AYALA, 1974, p. 38).

Kelsen afirma isso porque para ele a estrutura necessária, que desde os primitivos sempre esteve presente no entendimento humano, era já uma relação de imputação, ou princípio de retribuição. Esse é um ponto esclarecedor de como Kelsen passa a ver toda a ordem social (direito e Estado) como nexos imputativos, o que o levou a considerações sobre a primazia da normatividade em relação à causalidade como princípio gnosiológico. Inata ao homem seria a busca de "responsáveis", e não de "causas":

Se examinarmos o modo pelo qual a idéia de causalidade se desenvolveu na mente humana, descobriremos que a lei da causalidade tem sua origem em uma norma. A interpretação da natureza tinha originalmente um caráter social. O homem primitivo considerava a natureza como parte intrínseca de sua sociedade. Ele interpretava a realidade física segundo os mesmos princípios que determinavam suas relações sociais. Para ele, sua ordem social era, ao mesmo tempo, a ordem da natureza. Assim como os homens obedecem às normas da ordem social, as coisas obedecem às normas que emanam de seres pessoais sobre-humanos. A lei social fundamental é a norma de acordo com a qual o bem tem de ser recompensado e o mal, punido. Segundo esse princípio de retribuição, o homem interpreta a natureza. Sua interpretação tem um caráter normativo-jurídico. (KELSEN, 1945, p. 65-66).

Isso, bem compreendido, significa que Kelsen se posiciona contra Kant no que diz respeito às condições a priori do conhecimento da natureza, apesar de usar o argumento kantiano para justificar as condições a priori do conhecimento jurídico.

As diferenças entre Kant e Kelsen não param aí. Segundo análise de Alida Wilson, o jurista austríaco variou sua própria concepção de imputação (em alemão, Zurechnung), que ora aparece como um princípio metodológico, ora é uma categoria, ora depende da experiência, ora é lógico transcendental e a priori. Segundo a autora, Kant, 
ao buscar o a priori, não separa o conhecimento da filosofia moral, que vai resultar na concepção de uma razão prática. Já Kelsen não admite uma razão prática porque esta se apoia na liberdade (e não tem comunicação com a necessidade teórica) e contraria Kant quando este defende que o homem natural e o homem moral (sein e sollen), em última análise, devem ser vistos como uma só realidade cognoscível. ${ }^{7}$

Surgem outras dúvidas nas passagens em que o assunto é tratado expressamente. Em outro momento, a causalidade de Kant corresponde ao que é a imputação de Kelsen, induzindo à conclusão de que na verdade o princípio de causalidade é mesmo uma categoria, renomeada para o campo jurídico, restando assim salva por aquela natureza a priori outrora negada:

A imputação é, da mesma forma que a causalidade, um princípio ordenador do pensamento humano e, por isso, é, tanto ou tão-pouco como aquela, uma ilusão ou ideologia, pois - para falar com Hume ou Kant — também aquela não é mais que um hábito ou categoria do pensamento. (KELSEN, 1960, p. 158).

Para compreender as verdadeiras explicações históricas do pensamento kelseniano e de sua problemática filiação a Kant, é necessário tratar da ligação de Kelsen a outros movimentos filosóficos de influência kantiana, iniciados já no século XIX, grosso modo denominados neokantismo, com os quais o jurista austríaco flerta para construir um modelo a partir de Kant, mas em certo sentido contra ele.

\section{Contra Kant: o formalismo e a negação da metafísica}

A compreensão exata dos fundamentos da obra de Kelsen requer um avanço da análise em direção aos movimentos filosóficos inspirados pelo pensamento kantiano e desenvolvidos no final do século XIX e início do XX: as chamadas escolas neokantianas. São basicamente duas escolas filosóficas que representaram um momento importante na filosofia ao reagirem contra os críticos de Kant, notadamente os adeptos do irracionalismo romântico germânico. Os neokantianos, portanto, apegaram-se ao racionalismo como fundamento de suas teses, postulando um "retorno a Kant", ainda que apresentando desenvolvimentos diferentes da doutrina kantiana, negando algumas de suas premissas.

O neokantismo seguiu dois caminhos distintos: por um lado, a Escola de Baden, cujos expoentes mais conhecidos foram Heinrich Rickert e Wilhelm Windelband, os quais desenvolveram uma teoria do conhecimento baseando-se nos valores que os

WILSON, Alida. Is Kelsen really a Kantian? In: TUR, Richard; TWINING, William (Org.). Essays on Kelsen. Oxford: Clarendon Press, 1986. passim. 
juízos constituem acerca do objeto a ser conhecido. Buscavam uma fundamentação transcendental dos valores para compreender a objetividade e a subjetividade das experiências axiológicas. Por outro lado, a Escola de Marburgo, cujos principais expoentes foram Hermann Cohen, Ernst Cassirer e Paul Natorp, desenvolveu uma teoria do conhecimento depurando o processo cognitivo de resquícios metafísicos em busca do método formalmente válido.

Kelsen defendeu a força do pensamento normativo, a autonomia de um mundo do dever-ser, como uma instância racional despregada da metafísica e do subjetivismo fundamentando-se nas ideias da Escola de Baden, mais especificamente no pensamento de Wilhelm Windelband, para quem os valores reconhecidos no juízo compõem um dever-ser diverso da moral, autônomo, desvinculado de subjetivismos. Para Kelsen, seguindo essa linha, o dever-ser jurídico é independente do dever-ser ético. No dizer de Recaséns Siches:

[Para Kelsen] Siguiendo a Windelband, el 'deber ser jurídico’ es considerado como un concepto completamente independiente del deber ser ético, como la expresión de la autonomía del Derecho. (RECASÉNS SICHES, 1963, p. 141).

A concepção de um dever-ser como valor dado pelo entendimento, contraposto ao mundo dos fatos e da natureza, provinha de Kant, mas sua independência em relação à ética é uma significativa ruptura dos neokantianos com o mestre de Köenigsberg. Segundo Legaz Y Lacambra, essa tese está presente numa das primeiras obras de Kelsen, os Hauptprobleme de 1911. Ali, o Autor se apoia nos Prelúdios, ensaios e discursos de introdução à filosofia, de Windelband, para então distinguir totalmente os mundos do ser e do dever-ser, o pensamento causal e o normativo:

Empero, los Hauptprobleme aparecieron directamente influenciados por la filosofía de los neokantianos de BADEN, (Südwestdeutsche Schule), tal como la expuso WINDELBAND y, en parte RICKERT. La distinción entre norma y ley natural, que tan importante papel juega en la fundamentación de la Jurisprudencia kelseniana, procede de este pasaje de los Preludios: "Las leyes psicológicas son, por tanto, principios de la ciencia explicativa, de los que tiene que ser derivado el origen de los hechos particulares de la vida anímica: representan — conforme a la condición fundamental de toda ciencia explicativa las determinaciones generales en virtud de las cuales cada hecho particular de la vida anímica tiene que formarse necesariamente tal como de hecho se forma. La Psicología explica con sus leyes cómo pensamos, sentimos, queremos y obramos realmente. Por el contrario, las leyes que encontramos en nuestra conciencia lógica, ética y estética 
no tienen nada que ver con la explicación teorética de los hechos a que se refieren. Se limitan a expresar cómo deben ser realizados estos hechos para que, con validez general, puedan ser juzgados como verdaderos, como buenos, como bellos. No son, por tanto, leyes que expliquen cómo tiene que verificarse el acaecer objetivo o cómo podrá ser subjetivamente concebido, sino normas ideales para juzgar del valor de lo que necesariamente sucede. Así se ve que nuestra vida psíquica es considerada a través de dos prismas radicalmente diversos, por las dos legislaciones a que está sometida y, por tanto, éstas no pueden entrecruzarse en su esfera de acción. Para la legislación psicológica la vida anímica es un objeto de ciencia explicativa; para la legislación normativa de la conciencia ética, lógica y estética, es objeto de un juicio ideal. Por las leyes naturales concebimos hechos; por las normas los aprobamos o desaprobamos. Las leyes naturales pertenecen a la razón que concibe: las normas a la razón que valora. Jamás una norma es un principio de explicación, como la ley no lo es nunca de la valoración" (WINDELBAND, 1915 v. 2, p. 67). Todo el normativismo kelseniano está ahí. (LEGAZ Y LACAMBRA, 1933, p. 175-176).

Essa tese de Windelband é a base para que se conceba a existência do mundo dos valores, do direito e da ética, mas rejeita a possibilidade de os valores serem tratados de um modo teórico, isto é, como ocorre com o mundo da natureza, do ser. A filiação de Kelsen à escola de Baden reafirma a separação entre ser e dever, mas não admite que os deveres possam ter conteúdos teorizáveis, mormente se apoiados na ideia de liberdade, como propõe Kant.

A filiação de Kelsen à outra escola neokantiana, de Marburgo, aparece mais indireta, apesar de Kelsen afirmá-la textualmente. Os marburguenses apregoavam uma lógica transcendental absolutamente destituída de conteúdos empíricos, postulando que apenas o pensamento é suficiente para conhecer os objetos e tudo o que está fora dele é contraditório, pois não há ser senão o "ser pensado". Nesse ponto, contrariavam a doutrina kantiana ao negar a dependência da razão pura em relação à sensibilidade na constituição do conhecimento. O fundamento do conhecimento possível não provém da experiência, mas surgiria para Kant numa relação última com ela, isto é, por intermédio das intuições sensiveis do espaço e do tempo. Para Cohen, ao contrário, só se poderia pensar a realidade em termos conceituais e puros do entendimento, sem buscar as origens do conhecimento numa sensibilidade exterior ao pensamento puro e conceitual. ${ }^{8}$

Sobre isso, diz Abbagnano: "Cohen rejeita a distinção kantiana entre intuição e pensamento, distinção pela qual o pensamento teria o seu princípio em algo que lhe seria externo. O pensamento não é síntese, mas 
Uma primeira influência da Escola de Marburgo na obra de Kelsen se explicaria pela necessária radicalização da fundamentação do conhecimento sem apelo às formas da sensibilidade. Isso serviria à possibilidade de conhecimento de uma ordem jurídica com a separação entre ser e dever-ser numa nova interpretação transcendental. A raiz de toda fundamentação da validade permitiria o conhecimento do direito e dispensaria qualquer elemento empírico, fático, contingente e histórico. Bastaria a identificação do "dever-ser", das estruturas formais e das relações lógicas, afastada de qualquer influência do mundo do "ser" (tanto dos conteúdos das normas como de sua eficácia) para que se possa conhecer uma ordem jurídica e lhe atribuir validade.

Uma outra razão para a possível ligação de Kelsen ao formalismo rigoroso de Marburgo é que este transformava a filosofia neokantiana em um ponto de apoio contra alguns elementos da doutrina kantiana em que se via a mistura entre forma ( $a$ priori) e conteúdo (liberdade), notadamente na concepção do direito natural elaborada por Kant. Nesse sentido, a busca de fundamentos no dualismo ser e dever-ser começaria nas teses lançadas pelo neokantismo de Baden e se concluiria com o formalismo teórico do neokantismo de Marburgo. A construção de uma teoria pura do direito necessitava de uma razão teórica, que explicasse o direito por meio de proposições (e não imperativos categóricos de uma razão prática) e que o compreendesse livre de conteúdos predeterminados, seja de origem empírica seja de origem metafísica (ideias da razão), como é o caso da liberdade para Kant. Eis a necessidade de uma concepção não estática, mas dinâmica dos diversos fenômenos jurídicos:

Los conceptos puros de conocimiento de Kant, o categorías, la forma de la experiencia, tenían una función creadora en que sólo por medio de su síntesis era como las impresiones sensitivas podían llegar a ser asunto de la cognición. Hermann Cohen, líder de los neokantianos de Marburgo, con la cual se había aliado abiertamente Kelsen, dio a este principio fundamental su última expresión al substituir el princípio de síntesis de Kant, que todavía contenía elementos estáticos, por un princípio de creación puramente dinámico. ${ }^{9}$ (EBENSTEIN, 1947, p. 50).

antes produção (Erzeugung), e o princípio do pensamento não é um dado, independente dele de um ou outro modo, mas a origem (Ursprung). A lógica do conhecimento puro é a lógica de origem". (ABBAGNANO, Nicola. História da filosofia. Lisboa: Presença, 1995. v. 8, 12. p. 133, § 730).

9 Nota de EBENSTEIN, William. La teoría pura del derecho. México-B. Aires: Fondo de Cultura Económica, 1947. p. 50: "El decisivo punto de vista epistemológico para la correcta construcción de los conceptos del derecho y del estado lo adquirí a través de la interpretación de Kant por parte de Cohen”. KELSEN, Hans. Hauptprobleme der Staatsrechtslehre, entwickelt aus der Lehre vom Rechtssatz. 2. ed. Tübingen: Mohr, 1923. XVII. 
E é assim que o principal apoio de Kelsen no neokantismo de Marburgo ao idealismo kantiano entra na polêmica acerca da "coisa em si" e suas repercussões para a ética. Segundo os neokantianos desse movimento, ao mesmo tempo em que Kant negara a metafísica tradicional por esta aplicar a razão pura ao vazio ou postular o conhecimento das coisas independentemente da consciência, ele próprio formulou uma metafísica semelhante ao admitir a "coisa-em-si" como "ideia da razão". O neokantismo, ao invés, pretendendo abandonar qualquer resquício de metafísica na identificação das possibilidades do conhecimento, não podia admitir a "coisa em si", pois as construções que o entendimento elabora sobre o real não levariam ao conhecimento efetivo das coisas mesmas nem mesmo como ideia reguladora.

Seguindo essa postura de afastamento radical de qualquer elemento metafísico nos processos de obtenção (e fundamentação) do conhecimento científico, uma teoria pura do direito também não poderia admitir qualquer metafísica no conhecimento do direito. Seus pressupostos formalistas não permitiriam que os conteúdos do direito fossem natural ou racionalmente imutáveis ou que seu fundamento fosse divino. Eis a base de toda crítica de Kelsen ao jusnaturalismo, concepção que seria insustentável pelo fato ser impossível à teoria do direito identificar conteúdos de um direito "em si" ou elementos "estáticos" e do mesmo modo não poder fundamentar esse conhecimento em qualquer conhecimento externo ao sujeito pensante, em Deus ou na natureza. As próprias palavras de Kelsen sobre Kant o revelam:

O papel que a "coisa em si" desempenha no seu sistema revela muito de transcendência metafísica. Por esse motivo, não encontramos nele uma confissão franca e intransigente de relativismo, a conseqüência inevitável de qualquer eliminação real da metafísica. Uma emancipação completa da metafísica era provavelmente impossível para uma personalidade ainda profundamente enraizada no cristianismo como a de Kant. Isso se torna mais evidente na sua filosofia prática. É exatamente aqui, onde repousa a ênfase na doutrina cristã, que o dualismo metafísico desta invadiu completamente o seu sistema, o mesmo dualismo que Kant combateu com tanta persistência na sua filosofia teórica. Nesse ponto, Kant abandonou o seu método de lógica transcendental. Esta contradição dentro do sistema do idealismo crítico já foi observada com freqüência suficiente. Assim acontece que Kant, cuja filosofia de lógica transcendental estava proeminentemente destinada a fornecer o fundamento para uma doutrina jurídica e política positivista, permaneceu, como filósofo jurídico, na rotina da doutrina do Direito natural. (KELSEN, 1945, p. 635-636).

Para Kant, a admissão da "coisa em si" como uma ideia vai ser a base da ética, uma vez que somos obrigados a pensar a liberdade como algo independente da 
experiência, que não é cognoscível, mas é uma ideia da razão que orienta o entendimento e possibilita a formulação racional do imperativo categórico: um querer racional segundo uma razão prática, determinada por leis da razão teórica:

Em contraste com as leis da natureza, essas leis da liberdade são denominadas leis morais. Enquanto dirigidas meramente a ações externas e à sua conformidade à lei, são chamadas de leis jurídicas; porém, se adicionalmente requerem que elas próprias (as leis) sejam os fundamentos determinantes das ações, são leis éticas e, então, diz-se que a conformidade com as leis jurídicas é a legalidade de uma ação, e a conformidade com leis éticas é a sua moralidade. A liberdade à qual as primeiras leis se referem só pode ser liberdade no uso externo da escolha, mas a liberdade à qual as últimas se referem é liberdade tanto no uso externo como no interno da escolha, porquanto é determinada por leis da razão (KANT, 2008, p. 63).

Mas, como foi dito, Kelsen não podia conceber uma razão prática por sustentar radicalmente a separação entre os mundos do "ser" e o do "dever-ser". Segundo ele, o próprio Kant, que foi o pai dessa concepção dualista, não a levou adiante porque a vontade e a razão se repelem:

Dizer que uma norma é imediatamente evidente significa que ela é dada na razão, com a razão. O conceito de uma norma imediatamente evidente pressupõe o conceito de uma razão prática, quer dizer, de uma razão legisladora; e este conceito é (...) insustentável, pois a função da razão é conhecer e não querer, e o estabelecimento de norma é um ato de vontade. Por isso não pode haver qualquer norma imediatamente evidente. (KELSEN, 1960, p. 271).

E ainda:

Conhecimento é receptivo, querer é produtivo. Esta diferença é, no entanto, eclipsada na Teoria do Conhecimento de Kant, conquanto que, segundo esta, o conhecimento tem significação constitutiva, enquanto o conhecimento da razão cria de novo e diferente o caos do sentimento para uma ordem da natureza, assim como a razão prática cria a ordem da Moral. Mas ambas estas ordens são essencialmente diferentes; uma - uma ordem do ser, a outra - uma ordem do dever-ser. Aquela é criada pelo conhecimento; esta apenas pode ser criada pelo querer.

O conceito, em si contraditório, da razão prática, que, simultaneamente, é conhecer e querer, e no qual portanto é suprimido o dualismo do ser e dever-ser, é o fundamento da Ética kantiana. (KELSEN, 1979, p. 100). 
Assim, enquanto Kelsen fundamentou sua separação entre normatividade e causalidade no pensamento dos neokantianos de Baden, já que nem o próprio Kant teria levado essa distinção adiante, ele apreende dos neokantianos de Marburgo mais elementos para cimentar seu sistema formalista e antimetafísico. Esses são os fundamentos da teoria kelseniana admitidos pelo próprio Autor. Uma análise mais rigorosa seria necessária para por em termos mais conclusivos a leitura que Kelsen tinha dos neokantianos. ${ }^{10}$ Mas é possível partir desses fundamentos como hipóteses ou intenções do Autor para se analisar com mais cuidado quais são os princípios dos quais Kelsen não poderia abdicar para oferecer um sistema teórico consistente.

\section{Conceito elementar da norma fundamental (Grundnorm)}

Tendo em vista a explicação da norma fundamental como pressuposto lógico-transcendental e a identificação do alinhamento teórico de Kelsen à filosofia neokantiana, passa-se então para a questão de se a norma fundamental realmente é o que o jurista vienense pretendeu que fosse: uma categoria. Essa consideração pretende aclarar o conceito de validade kelseniano mostrando como o conceito sobrevive a críticas dos comentadores, resultando inclusive numa mudança de orientação na última fase de sua produção científica.

A referência à norma fundamental constante na segunda edição de sua Teoria Pura do Direito é identificada em um parágrafo paradigmático que trata de uma só vez de várias questões consideradas polêmicas pelos críticos:

Para efeito de podermos considerar as normas que conferem competência ao órgão legislativo como constituindo o sentido, não só subjectivo mas também objectivo, de um acto posto por determinados indivíduos, caracterizamos ou interpretamos estas normas como Constituição. Tratandose de uma Constituição que é historicamente a primeira, tal só é possível se pressupusermos que os indivíduos se devem conduzir de acordo com o sentido subjectivo deste acto, que devem ser executados actos de coerção sob os pressupostos fixados e pela forma estabelecida nas normas que caracterizámos como Constituição, quer dizer, desde que pressuponhamos uma norma por força da qual o acto a interpretar como acto constituinte seja de considerar como um acto criador de normas objectivamente válidas e os indivíduos que põem este acto como autoridade

10 Por exemplo, afigura-se complicada a citação de Kelsen sobre o caráter não-constitutivo da razão teórica em relação ao objeto de conhecimento, enquanto esse caráter constitutivo é afirmado notoriamente pelos neokantianos de Marburgo, com apoio em Kant. 
constitucional. Esta norma é (...) a norma fundamental de uma ordem jurídica estadual. Esta não é uma norma posta através de um acto jurídico positivo, mas - como o revela a análise de nossos juízos jurídicos - uma norma pressuposta, pressuposta sempre que o acto em questão seja de entender como acto constituinte, como acto criador da Constituição, e os actos postos com fundamento nesta Constituição como actos jurídicos. Constatar essa pressuposição é uma função essencial da ciência jurídica. Em tal pressuposição reside o último fundamento de validade da ordem jurídica, fundamento este que, no entanto, pela sua mesma essência, é um fundamento tão somente condicional e, neste sentido, hipotético. (KELSEN, 1960, p. 77, cap. 1, item 6, letra c. grifos no original).

Quando Kelsen afirma que só é possível analisar o sistema como um todo de sentido se pressupusermos que o primeiro comando de uma ordem escalonada é válido, isto é, que ele deve-ser, isso manifesta que essa pressuposição é uma necessidade lógica do sistema e da própria validade, numa palavra, um elemento ideal pensado, que gera uma dificuldade quanto à possibilidade de haver normas meramente pensadas (isto é, exatamente a crítica feita ao imperativo categórico de Kant).

O uso do condicional "se pressupusermos" no trecho citado, aliado a outras passagens de Kelsen, levou a questionamentos quanto a uma possível disponibilidade da norma fundamental, como se os teóricos tivessem a alternativa de ver a realidade normativa de outra forma que não necessariamente por meio de um conceito transcendental, o que então levaria ao afastamento da definição de norma fundamental como categoria a priori.

Outro problema que surge no excerto é saber quem pressupõe a norma fundamental. Kelsen, como se vê, primeiramente se manifesta em primeira pessoa do plural, o que não esclarece muita coisa; mas no mesmo parágrafo frisa que quem pressupõe a norma fundamental é o cientista do direito. Por fim, afirma que a norma fundamental é uma hipótese, pois sua pressuposição é condicional.

Essa é a definição básica que se extrai da leitura de toda a Teoria Pura do Direito: uma norma hipotética pensada logicamente pelo cientista por necessidade lógica (lógico-transcendental). O leitor atento ao texto lerá basicamente essas características que Kelsen atribui ao fundamento último de validade, sem maiores problemas. No entanto, como será melhor analisado, existem várias dificuldades do conceito que Kelsen tem de enfrentar, sendo que as questões aqui postas em relevo, acerca da disponibilidade da norma fundamental, de quem a pressupõe, de sua caracterização como norma meramente pensada e do fato de ser ela uma hipótese, geram dúvidas que exigem um delineamento melhor do conceito e um juízo crítico acerca de sua real natureza. 
7. O problema da norma fundamental como norma, válida e positiva

Como já foi tratado, a ideia de validade kelseniana implica uma relação entre normas, pois só se pode dizer que uma norma é válida se estiver relacionada a outra que lhe dá validade. Nesse ponto, a postulação de uma norma fundamental deu margem a uma primeira ordem de críticas, pois se a validade para Kelsen é relacional, a primeira norma do sistema não pode ser válida, porque não tem relação com nenhuma outra que lhe atribui validade. Mas Kelsen diz que é válida e realmente só faz sentido que uma primeira norma atribua sentido objetivo a outra se ela for válida. Nesse caso, em algum lugar do sistema a validade não seria mais relacional, mas absoluta, estritamente no caso do fundamento último de validade: uma validade pressuposta. ${ }^{11}$

A norma fundamental é, ou melhor, tem de ser pressuposta como válida. A partir da dúvida inicial sobre sua validade, surgem outras, explicitadas majoritariamente por García Amado. Com o perdão da aparente tautologia, seria a norma fundamental realmente uma norma? ${ }^{12}$

Esse problema surge também na crítica que Alchourrón \& Bulygin fazem do conceito de norma fundamental. Para eles, se se trata de um critério último de atribuição de validade e concatenação lógica de um sistema, esse critério não pode ele mesmo ter característica de norma, manifestando Kelsen a tendência comum na filosofia do direito de identidade entre critério de validade e norma de competência:

Así, por ejemplo, en Kelsen la norma básica, no sólo
suministra el criterio último de validez de todo el orden
jurídico, sino que, además, otorga competencia al primer
legislador. Pero es claro que una definición no puede
otorgar a nadie competencia para crear normas jurídicas.
(...) (ALCHOURRÓN \& BULYGIN, 1998, p. 120, nota 8).

A rigor, essa identificação entre critério e norma é proibida, pois está fundamentada na distinção entre ciência do direito (que, no âmbito descritivo dita o critério) e seu objeto (que é prescritivo). E, de fato, como ressalta Paulson, o próprio Kelsen, em um momento anterior de sua produção científica (1928), chegou a afirmar que a norma fundamental era uma proposição:

(La fórmula de la norma fundamental no reza) - como a veces se dice abreviadamente: debe ocurrir lo que la suprema autoridad estatuye, sino precisamente: bajo las condiciones que determina la autoridad suprema debe

\footnotetext{
11 Assim, FERRAZ JR., Tercio Sampaio. Introdução ao estudo do direito. São Paulo: Atlas, 1994. p. 186, item 4.3.1.4

12 GARCÍA AMADO, Juan Antonio. Kelsen y la norma fundamental. Madrid: Marcial Pons, 1996. passim.
} 
ejercerse la coacción determinada por esa autoridad y sólo en el modo que ella determina. La norma fundamental tiene la forma de proposición jurídica, la norma fundamental de la ley jurídica. (KELSEN. Philosophische Grundlagen, 1928 (nota 6), p. 25, reimpresso em Wierner Schule v. 1, p. 299, apud PAULSON, 2000, p. 172 - grifos do original de Kelsen).

Isso não significa que a norma fundamental não possa ser uma norma sentida pelos operadores do direito como tal e descrita pela ciência como norma, mas como norma última racionalmente identificada — e aqui já se vê ampliar o problema quanto a quem percebe tal norma. Por isso Santiago Nino contraria a crítica de Alchourrón \& Bulygin:

De hecho, la solución de Kelsen al último problema puede ser parafraseada de esta forma: "Un conjunto de normas constituyen un sistema jurídico unitario cuando adscribimos validez a todas ellas sobre la base de una y la misma norma básica". Por supuesto, la frase entre comillas no es una paráfrasis de la norma básica o de otra norma, ella formula un criterio de individualización que puntualiza la circunstancia de que la misma norma básica es presupuesta cuando adscribimos validez a todas las normas del mismo sistema jurídico. Por eso, autores como Alchourrón y Bulygin están equivocados cuando critican la norma básica de Kelsen sobre la base de que lo que es necesario para la individualización de un sistema jurídico es un criterio y no una norma. La norma básica de Kelsen establece la obligatoriedad de un sistema jurídico; su identidad está determinada por un criterio que toma en cuenta el hecho de que la misma norma básica es presupuesta cuando adscribimos obligatoriedad a todas las normas del sistema. (NINO, 1985, p. 13-14).

Vê-se, assim, que para Santiago Nino a norma fundamental é identificada como norma ainda por um outro critério, anterior, o que parece gerar ainda mais dificuldades sobre o fundamento de validade envolvido nesse ponto. A solução diante de interpretações tão díspares do mesmo conceito parece difícil. Parece, entretanto, que dessas interpretações pode-se ensaiar uma terceira, eclética, que se assume por ora. A norma fundamental poderia ser norma, enquanto comando-sentido, usado e sentido como válido pelos aplicadores do direito. E ao mesmo tempo um critério último de identificação do direito, para o cientista do direito, sem o qual não há dever-ser algum.

Kelsen, apesar do citado trecho de 1928 em que parece dizer que é proposição, em inumeráveis outras passagens posteriores afirma que a norma fundamental é norma, pois tem o sentido de dever-ser, um sentido normativo de comando; por isso, diferente de uma proposição que afirma um postulado básico. Ademais, é norma porque 
se o fundamento de validade de uma norma sempre está em outro dever-ser, assim a primeira norma positiva do sistema jurídico só pode ser norma se sua validade estiver fundamentada em uma norma.

Além disso, é a norma fundamental uma norma jurídica, ou pode ser uma norma moral? É norma positiva? Essa questão levantada será enfrentada em capítulo à parte, em que vem à baila a tese de Santiago Nino segundo a qual o fundamento kelseniano de validade contém implicitamente uma justificação de ordem moral. É Kelsen quem, noutro texto, refere essa possibilidade ao afirmar que a norma fundamental não tem natureza positiva, nem jurídica:

Admito que sólo se puede hablar de la validez de un Derecho positivo bajo una presuposición que nos es ella misma jurídica. Esto lo he repetido sin parar, cientos de veces. Pero yo no he afirmado que esta presuposición sea Derecho. No es Derecho positivo. Qué sea, esa es otra cuestión. Yo no veo aquí nada más que una presuposición hipotética, fingida. (KELSEN «Die Grundlage der Naturrechtslehre» in Franz-Martin Schmölz, Das Naturrecht in der politischen Theorie; apud GARCÍA AMADO, 1996, p. 29).

Assim, vê-se que a norma fundamental é norma, é válida, mas não é ela mesma Direito, pois não é norma positiva - como já afirmara Kelsen no trecho citado em que aparece o conceito elementar da Grundnorm. Porque se a norma fundamental é já o critério definidor do direito, se se quisesse saber se é ela mesma Direito seria necessário outro critério e assim por diante, infinitamente. Até aqui, no entanto, a postulação da validade parece estar muito bem protegida pelo status de categoria lógico-transcendental, já que esta definição dá conta do problema por meio de uma solução epistemológica em que o critério é um dado a priori do entendimento, que evidentemente não precisa ter um elemento positivo.

\section{O problema da norma fundamental como norma disponível}

Mas outro problema identificado por García Amado tende a colocar em xeque todo o raciocínio que Kelsen sustentou acerca da natureza da norma fundamental nos referidos termos neokantianos. É que identificada uma disponibilidade da norma fundamental, esta não mais seria uma categoria. Nesse ponto, as críticas parecem já identificar um comprometimento da grande tese de Kelsen:

Una nota crucial de la norma fundamental de Kelsen es lo que vamos a llamar disponibilidad. Alude este carácter a que no es la norma básica una realidad que se imponga con necesidad a quien contempla los hechos que sirven de soporte al Derecho. Cabe la opción de ver dichos 
hechos meramente como tales (un acto de voluntad de un sujeto o grupo de sujetos, un acto de fuerza de quien tiene poder fáctico...), o la de verlos en su dimensión de juridicidad, como actos jurídicos y normas jurídicas, para lo que se requiere la presuposición de la norma básica como fundamiento ultimo. Esa es la parte de disponibilidad de la norma básica. Pero si se opta por ver el Derecho, por asumir que, más allá de los meros hechos, hay Derecho, no se dispone de la libertad de verlo en los actos o voluntades que se quiera, sino únicamente en el orden que sea eficaz por encima de cualesquiera otros. Aquí, en este aspecto, nos hallamos con la eficacia, en tanto que dato objetivo, como límite a la libre configuración intelectual de la norma fundamental y, con ello, del Derecho.

Insiste Kelsen abundantemente en que «no es necesario presuponer la norma básica» en el sentido de que no existe ningún género de compulsión intelectual que fuerce a los sujetos a dar por sentada esa norma y, con ello, a aceptar la especificidad de lo jurídico.

Pero sólo si presuponernos esa norma «podemos considerar a un orden coercitivo, que es generalmente eficaz, como un sistema de normas objetivamente válidas» (KELSEN, «El Profesor Stone y la Teoría Pura del Derecho», apud GARCÍA AMADO, 1996, p. 53).

A crítica é tão direta e comprometedora que requer uma análise mais profunda. Se García Amado estiver certo ao dizer que não há nada que force o sujeito a pressupor uma normatividade, então sua natureza a priori cai por terra. Também Stanley PAUSON traz à baila um trecho semelhante de Kelsen no qual ele "admite de manera expresa la explicación alternativa del fenómeno en cuestión desde el punto de vista de los empiristas, o mejor, escépticos." (PAULSON, 2000, p. 120). Nas palavras de Kelsen:

Solo cuando se presupone esta categoría normativa se puede diferenciar entre actos imperativos legales e ilegales, interpretar relaciones interpersonales objetivamente como relaciones jurídicas, o sea como deberes jurídicos, autorizaciones, competencias. Sin embargo, esta es sólo una interpretación posible, posibilitada por el presupuesto de la categoría normativa, no una interpretación necesaria. Las relaciones interpersonales podrían también interpretarse como simples relaciones de poder, es decir, como causalidad. ("Von Geltungsgrund des Rechts", In: Völkerrecht und rechtliches Weltbild, Festschrift für Alfred Verdross, Wien 1960, p. 157 a 165, reimpresso em Wierner Schule, v. 2 (nota 2), p. 1.417 a 1.427, apud PAULSON, 2000, p. 119 grifos do original de Kelsen). 
Entretanto, se ambos os autores tiverem razão quanto à negação do estatuto de categoria à norma fundamental, não é por tais fundamentos. Se a norma fundamental deixa de ser categoria, não parece ser apelando para esses trechos de Kelsen, em que, se melhor analisados, revelam um argumento do autor em reforço à necessidade da norma fundamental:

Dizer que podemos pressupor a norma fundamental de uma ordem jurídica positiva mas que não temos necessariamente de a pressupor significa que podemos pensar as relações inter-humanas em questão normativamente, isto é como deveres, poderes, direitos, competências, etc. constituídos através de normas jurídicas objectivamente válidas, mas não temos de as pensar necessariamente assim; que as podemos pensar sem pressupostos, quer dizer, sem pressupor a norma fundamental, como relações de força, como relações entre indivíduos que comandam e indivíduos que obedecem ou não obedecem - isto é, sociológica e não juridicamente. (KELSEN, 1960, p. 305, cap. V, 34, i - grifo nosso).

O fato de Kelsen dizer que a pressuposição de validez não é necessária, ou que podemos pressupor a norma fundamental não contradiz sua afirmação de que só é possível compreender um sistema prescritivo como jurídico pressupondo sua obrigatoriedade numa última instância. Ora, analisando essas ideias, Kelsen parece dizer não que a compreensão do elemento especificamente jurídico de uma sociedade seja uma faculdade do cientista do direito, mas exatamente o contrário: que só se pode compreender uma realidade juridicamente se e somente se uma norma fundamental for pressuposta. Se se quiser analisar os mesmos dados como fatos, faz-se sociologia - e então, como se viu, já se tratará de outra realidade — mas nunca teoria jurídica que explique a normatividade e a validade. Por isso, em nota de rodapé ao mesmo trecho, Kelsen diz que mesmo um anarquista pode, como jurista, pressupor a norma fundamental, se bem que não o faça por motivos políticos. ${ }^{13}$

13 Diz ali Kelsen: “O exemplo por mim anteriormente escolhido para ilustrar a pressuposição, simplesmente possível e não necessária, da norma fundamental: Um anarquista não pressupõe a norma fundamental, induz em erro. O anarquista rejeita emocionalmente o Direito como ordem coerciva, desaprova-o, deseja uma comunidade livre de coacção, não constituída por uma ordem coerciva. O anarquismo é uma posição política, baseada num determinado desiderato. A interpretação sociológica, que não pressupõe a norma fundamental, é uma posição teorética. Também um anarquista pode, como jurista, descrever um Direito positivo como um sistema de normas válidas sem aprovar este Direito. Muitos tratados nos quais uma ordem jurídica capitalista é descrita como um sistema de normas constitutivas de deveres, poderes, direitos e competência foram escritos por juristas que politicamente desaprovavam essa ordem jurídica". (1960, p. $305)$. 
Numa nota à Teoria Pura do Direito em que Kelsen se dedica longamente a combater o realismo de Alf Ross, Kelsen igualmente explica essa disponibilidade da norma fundamental em termos similares:

Com efeito, ela [a Teoria Pura do Direito] acentua com ênfase que a afirmação de que o Direito tem validade objectiva, quer dizer, que o sentido subjectivo do acto legislativo é também o seu sentido objectivo, é apenas uma interpretação possível - e possível sob uma determinada pressuposição —, e não uma interpretação necessária destes actos, que é inteiramente possível não atribuir um tal sentido aos actos legislativos. Isto não é, porém, razão para desqualificar o conceito da validade objectiva de dever-ser do Direito como racionalização da crença na autoridade ou competência da instância legisladora. (1960, p. 296-297 — 1ª nota de rodapé ao Cap. V, item $1^{\circ}$, letra g).

Isso demonstra que a questão se resolveria a priori para Kelsen, pois é a partir da distinção entre ser e dever-ser que se torna possível dar dois sentidos diversos a um mesmo dado fenomênico sem duplicar uma mesma realidade. A admissão de dois métodos de estudo, um causal, outro imputativo gera, segundo a visão neokantiana de que o método constitui o objeto de estudo, duas realidades: um fato jurídico-sociológico e um dever jurídico. Assim a morte de uma pessoa pode ser vista pela jurisprudência sociológica como a descrição de que uma provável sanção do Estado virá, e diversamente, vista pela jurisprudência normativa como evento gerador de um dever-ser. Isso Kelsen reconhece de forma clara na sua Teoria Geral do Direito e do Estado, bem como na primeira edição da Teoria Pura do Direito, assim respectivamente:

Todo ato que, de um ponto de vista jurídico, é um "delito" é também um fenômeno que pertence ao domínio da sociologia do Direito, na medida em que existe uma possibilidade de que os órgãos da sociedade reagirão contra ele executando a sanção estabelecida pela ordem jurídica. (KELSEN, 1945, p. 257).

"(A la Teoría Pura del Derecho) no se le oculta que esa significación específicamente normativa de ciertos hechos designada como "Derecho" es el resultado de una interpretación posible que se da ante un supuesto básico determinado - que luego ha de precisarse resultado de una interpretación necesaria; que no puede probarse la existencia del derecho como la de los hechos naturales y de las leyes naturales que los rigen; que no es posible refutar con argumentos obligatorios una postura como quizás la del anarquismo teórico que rehúsa ver algo diferente a la pura fuerza allí donde los juristas hablan de Derecho". (KELSEN, 1934, p. 65). 
Mas a tese de Kelsen é que a descrição do direito, de sua validade, de sua normatividade, só pode ser feita por meio do método normativo, dessa pressuposição normativa, como se dissesse: Quem compreende que há um nexo de dever-ser completamente diverso do nexo causal, necessariamente terá de pressupor um dever-ser $a$ priori. No máximo, a jurisprudência sociológica pode oferecer elementos complementares para a consideração da eficácia das normas, mas nunca pode explicar a validade, de modo que sua oposição a Ross, por ser um embate epistemológico, apareceria como um diálogo de surdos, já que da leitura se depreende que Kelsen só seria convencido quando Ross lhe provasse como o fato de abrir-se uma porta elimina o sentido do dever permanecer fechada. Por isso, Kelsen conclui o trecho acima citado da sua Teoria de 1934:

Mas la Teoría Pura del Derecho no cree necesario deducir de ahí la consecuencia de que sea menester renunciar a la categoría del deber ser en general, y con ella una teoría normativa del Derecho (...). Es imposible substituirla por la Sociología del Derecho, porque ésta se halla orientada hacia un problema bien diverso del de aquella. (1934, p. 65).

Desse modo, dizer que a norma fundamental não se sustenta transcendentalmente por ser disponível ou porque se pode ver a norma como o fato que lhe dá suporte seria o mesmo que dizer que a causalidade kantiana não é a priori porque se pode ver a chuva não como resultado do encontro de massas de ar, mas como consequência de uma imputação de uma autoridade a uma causa de natureza ética tal como, segundo Kelsen, pensavam os povos primitivos: recompensa pelas oferendas à divindade.

Daí que os argumentos de García Amado e de Stanley Paulson quanto a esse ponto se tornem pouco fundamentados, pois assumem que para o conhecimento da realidade natural as categorias são apriorísticas, mas para o conhecimento jurídico a norma fundamental é disponível, pois se pode apreender o fenômeno também do ponto de vista da realidade natural (ou social):

Las categorías kantianas son presupuesto ineludible y apriorístico de todo conocer de la realidad natural, de modo que nadie puede desembarazarse o hacer abstracción de ellas y captar esa realidad de otra forma, bajo otra óptica, en otras coordenadas. (GARCÍA AMADO, 1996, p. 109).

(...) La norma básica es instrumento necesario de un modo de conocer no necesario. (idem, p. 110).

Os defeitos da tese da norma fundamental são sustentados em outros termos. O apoio de Kelsen na doutrina kantiana é visto de forma problemática entre alguns estudiosos de Kant. Como afirmara Alida Wilson, o princípio de imputação (Zurechnung) teria sentidos diversos na Teoria Pura do Direito, não-só de categoria. García Amado concluiu pelas mesmas dificuldades: 
Se ha dicho que la circunstancia de que en unas ocasiones KELSEN diga que la «norma básica» es una categoría trascendental al modo kantiano y otras veces atribuya esa condición a la categoría de «imputación» es ya prueba de la imprecisión con que KELSEN usa los términos de la filosofía de KANT, pues «la norma básica y el principio de Zurechnung son diferentes y no está claro a qué propósito el calificativo "condición lógico-trascendental" es aplicable a ambos». (citação final entre aspas de ALIDA WILSON, «Josef Raz on Kelsen's Basic Norm», American Journal of Jurisprudence, 27, p. 48, apud GARCÍA AMADO, 1996, p. 111 nota 150$)$.

Para Roberto José Vernengo, é a norma fundamental e não a imputação, o que tem vários sentidos, deixando de ser considerada exatamente uma categoria, pois ela pode ter o sentido de um esquema prévio a qualquer consideração transcendental, um esquema anterior até mesmo ao conceito de categoria. Segundo essa visão, a imputação seria a categoria propriamente dita enquanto a norma fundamental seria o esquema anterior que permite a aplicação da imputação aos fatos:

Kelsen assigns different functions to the Grundnorm in its second sense (i.e. not as a pure epistemological category). The core of these functions consists in being the ultimate theoretical criterion for conferring normative validity, in an objective manner (i.e. intersubjectively), to the normative material that the legal scientist tries to describe and to systematize. The Grundnorm, in that sense, is for Kelsen also a norm, not only from a syntactical but also from a semantical point of view as well. It is not a positive norm because it has not been willed by any law-creating organ.

The basic norm has no source. It has to be envisaged as a mere presupposition of whatever type of objective legal knowledge is to be attained. Objective legal knowledge is a possible theoretical endeavor that sometimes, in some cultures, lawyers (legal scientists) can bring about by elaborating certain empirical data. (...)

For Kelsen, as for any neo-kantian, there could not be an object, as object of objective knowledge (science), before it is epistemologically constituted or constructed. The construction of the object - in our case, law — requires not only a logically well-structured language, but also a congruent set of categories. Only in that logical space would it be possible to work out a scheme through with some transcendental category would specify what is law and what is not. This function, in Kelsen's work, is fulfilled by the Zurechnung as category and the Grundnorm as its 
scheme. For Kelsen, there is no law in itself, with its own nature and proper characteristics, before it is constituted as such by the objective knowledge of positive jurisprudence. (VERNENGO, 1986, p. 103-105).

Segundo essa visão, que ainda carrega a ideia da descrição jurídica como algo "possível, mas não necessário", melhor talvez seria descrever a norma fundamental como um esquema social de interpretação que se assume ou uma "expresión simbólica o figurada de una fe socialmente compartida en la juridicidad del orden que se tilda de jurídico" (García Amado, 1996, p. 54). No final, segundo esses autores, a norma fundamental seria necessária apenas para os adeptos de uma epistemologia formalista e positivista, isto é, uma questão de opção.

Se se quiser analisar a norma fundamental dessa maneira, a sua descaracterização como categoria, do mesmo modo, não parece satisfatória, já que a descrição de Vernengo da Grundnorm como um esquema não parece dar sentido muito diverso ao conceito. $\mathrm{O}$ fato de poder ser descrita como um esquema epistemológico prévio parece apenas deslocar a questão da filosofia para o método, isto é, à pergunta "o que é a norma fundamental para a ciência do direito?" se responde que é uma opção epistemológica, quando não ainda por motivos suficientes ela deixaria de ser uma pressuposição lógico-transcendental, prévia.

Que seja um esquema epistemológico é sustentável e nesse caso ela teria uma função externa à ciência, que é o próprio papel da epistemologia, mas essa função não contraria o disposto por Kelsen quanto a sua função de fechar o sistema positivo, portanto ser uma norma internamente (cientificamente) descrita. Para fazer uma analogia, dizer que Kant adotou um esquema epistemológico organizador prévio para buscar na própria razão os fundamentos do conhecimento não implica que na sua explicação essa "arbitrariedade" contamine a natureza a priori das categorias do entendimento. Não é porque Kant crê num esquema filosófico idealista que suas categorias não podem ser consideradas transcendentais, até porque essa "opção" epistemológica é para ele a conclusão de uma dedução transcendental irrefutável.

Do mesmo modo, as dúvidas sobre uma filiação exata de Kelsen à filosofia ou à terminologia kantiana, na correta análise de García Amado, são pertinentes, mas constituem um argumento disponível quando se está analisando a função do conceito mais que os problemas terminológicos em torno da categoria.

Assim sendo, essa disponibilidade da norma fundamental, devidamente compreendida, não a descaracterizaria como categoria kantiana, sendo necessário analisar críticas mais subsistentes sobre a filiação de Kelsen a Kant para concluir por outros motivos determinantes se houve uma desvinculação do conceito de seu estatuto transcendental. 
Diversamente do que pode parecer, a argumentação que até aqui se desenvolve não visa a uma defesa transcendental da norma fundamental. Trata-se apenas de um esforço para esgotar essas críticas a partir de si mesmas, talvez como o próprio Kelsen possivelmente as rebateria segundo um "modelo kelseniano clássico". De fato, se a caracterização da norma fundamental como categoria é insustentável, não o é a partir das dificuldades apontadas e sim, mais precisamente, a partir da identificação de algumas aporias internas do modelo kelseniano, o que forçou uma mudança de concepção do próprio autor.

Portanto, se a norma fundamental não é categoria de um pensar estritamente jurídico, se é axioma ou esquema metodológico opcional ou se é disponível, talvez as verdadeiras razões se devam a três problemas internos do pensamento de Kelsen, identificados a partir da expressão clara do autor na clássica descrição do conceito de Grundnorm citada no paradigmático trecho já citado para apresentar o conceito basicamente (1960, p. 77): são problemas acerca da norma fundamental como hipótese, como norma pensada, e acerca de quem a pressupõe.

9. A norma fundamental pode ser uma hipótese?

Como já visto em trechos citados, Kelsen descreve sua norma fundamental como uma hipótese do pensamento jurídico científico. No entanto, o problema dessa caracterização é que uma hipótese científica deve implicar necessariamente a possibilidade de refutação pela realidade. Em outras palavras, a ideia de hipótese é oposta à ideia de necessidade pregada por Kelsen. Se realmente Kelsen admitisse que a norma fundamental é hipotética, definitivamente descaracterizaria seu conceito como categoria.

Nesse ponto, é necessário um esclarecimento do que seja a norma fundamental vista no sistema em movimento, pois se poderia argumentar que, como seu emprego ou sua determinação (conteúdo) só é possível a posteriori, ela poderia sim ser uma hipótese a ser verificada, pois teria seus conteúdos modificáveis conforme os ordenamentos históricos. Segundo esse argumento:
Algunos autores como J. Raz, han señalado que el proceso de suponer la norma fundamental sólo puede realizarse una vez que se ha identificado el sistema y no antes. Cuando realmente se sabe qué normas pertenecen al sistema jurídico entonces, y sólo entonces, es posible descubrir el contenido de la norma fundamental. Pero, si eso es cierto, la norma fundamental ya no fundamenta el sistema ni sirve tampoco para identificarlo. (MARTÍN, 1996, p. 53).

Esse raciocínio é causado por um equívoco básico. Esse sentido de hipótese diz respeito apenas à possibilidade de seu conteúdo ser refutada. Mas se a norma 
fundamental do ordenamento brasileiro for violada, isso não quer dizer que ela teria deixado em algum momento de fundamentar o sistema enquanto estrutura ideal, já que apenas mudou seu conteúdo. Nesse caso, portanto, até se poderia dizer que a norma fundamental é uma hipótese, mas num sentido diverso do proposto por Kelsen, pois para ele a norma fundamental seria hipotética em si, como estrutura presente em todo ordenamento, ideal e abstraída de seus conteúdos singulares deste ou daquele país. Se a norma fundamental brasileira "devemos obedecer ao que determinar o legislador constituinte escolhido pelo povo" modificar-se por meio de uma revolução para "devemos obedecer ao que o imperador disser", nem por isso a norma fundamental, na visão de Kelsen, teria deixado de estar presente como estrutura sem conteúdo, mesmo na passagem revolucionária.

O problema da hipótese, desse modo, permanece enquanto incompatível com a ideia de uma norma que não está em condições de confrontar-se com a realidade. Em outras palavras, o que é necessário - e a norma fundamental como categoria é necessária - não precisa, nem pode ser contrastado com a realidade, não podendo ser hipótese. Esse problema, no entanto, podia ter sido resolvido com uma trivial ressalva terminológica caso em que Kelsen até poderia dizer: — Realmente não pode ser hipótese; expressei-me mal; é categoria. O que parecia uma aporia interna pode ser resolvido com o afastamento do termo hipótese, pois se não for hipótese não há nenhum prejuízo teórico para a argumentação do autor. E é exatamente o que faz Kelsen em um trecho notável de sua Teoria Geral das Normas ao dizer que "é de se observar que a norma fundamental, no sentido da vaihingeriana filosofia do Como-Se, não é hipótese - como eu mesmo, acidentalmente, a qualifiquei - (...) porque a ela não corresponde a realidade (...). (KELSEN, 1979, p. 329, cap. 59-letra d.)

10. A norma fundamental é o sentido de um ato de vontade?

O problema da norma fundamental como norma pensada, por outro lado, não teria solução tão fácil. O conceito de norma kelseniano parte da uma relação com a vontade: normas são sentidos de atos de vontade. E essa afirmação contrasta diretamente com a definição de norma fundamental, que não pode ser querida:

Como esta norma fundamental não é uma norma querida e, por isso, também não pode ser uma norma querida pela ciência jurídica (quer dizer: pelo sujeito que faz ciência jurídica), e tal norma (melhor: a sua afirmação) é logicamente indispensável para a fundamentação da validade objectiva das normas jurídicas positivas, ela apenas pode ser uma norma pensada, e uma norma que é pensada como pressuposto quando uma ordem coercitiva globalmente eficaz é interpretada como um sistema de normas jurídicas válidas. (KELSEN, 1960, p. 284). 
Nesse trecho, há uma contradição teórica inafastável cujas alternativas são caras à estrutura do pensamento de Kelsen. Se norma é sempre um sentido de um ato de vontade, a norma fundamental tem de ser também um sentido de um ato de vontade para continuar a ser norma, mas se houver tal vontade suprema, ou Kelsen tem de admitir a vontade e não mais a razão como critério definidor último do seu conceito de validade, ou então continuar buscando o fundamento em outra norma que dê sentido objetivo à norma fundamental, mas assim não mais seria a norma base do sistema que, portanto regressaria ao infinito.

Originalmente, Kelsen refutara veementemente a ideia de uma norma fictícia, pois para ele isso implicaria aceitar as críticas anarquistas de que a sua teoria, no fundo, seria uma ideologia justificadora do poder dominante, já que suas bases nada teriam de racional e transcendental. Mas como todo dever-ser tem por base uma vontade — do contrário far-se-ia metafísica - a norma fundamental tem de ser uma norma querida e não pensada. É por aqui a trilha do argumento lançado contra Kant, segundo o qual a teoria pura do direito rejeita a ideia de uma razão prática. Por isso o seu conceito passa a ser descrito como norma fictícia, que não pode ser um "sentido de um ato de pensamento", mas tem de ser um "sentido de um ato de vontade".

Mas é de se reter aqui que, para a solução do problema, Kelsen mantém seus postulados idealistas ao máximo: ao invés de postular uma vontade suprema ou um poder originário ele visualiza ainda uma norma fundamental que pode ser não ela mesma, norma meramente pensada, mas uma norma baseada numa vontade meramente pensada. Se essa diferença é aceitável e a manutenção de algo como uma "vontade pensada" é satisfatória, alguns autores, dentre eles Norberto Bobbio, diriam que não. E seja norma pensada ou vontade pensada, isso contradiz de forma retumbante a tese kelseniana de que uma razão prática é uma contradição nos termos.

Inegavelmente, no entanto, a consequência dessa mudança de posição é o fato de que em sua Teoria Geral das Normas, Kelsen afasta não-só a ideia de que a norma fundamental é hipótese, mas também a de que é categoria transcendental:

O fim do pensamento da norma fundamental é: o fundamento de validade das normas instituintes de uma ordem jurídica ou moral positiva é a interpretação do sentido subjetivo dos atos ponentes dessas normas como de seu sentido objetivo; isto significa, porém, como normas válidas, e dos respectivos atos como atos proponentes de norma. Este fim é atingível apenas pela via de uma ficção. Por conseguinte, é de se observar que a norma fundamental, no sentido da vaihingeriana filosofia do Como-Se não é hipótese - como eu mesmo, acidentalmente, a qualifiquei - , e sim uma ficção que se distingue de uma hipótese pelo fato de que é acompanhada pela consciência ou, então, deve 
ser acompanhada, porque a ela não corresponde a realidade (...). (KELSEN, 1979, p. 329, cap. 59-letra d.).

Essa dificuldade aparece similarmente em outro texto, como identifica com precisão García Amado:

La primera vez que KELSEN modifica su descripción de la norma fundamental es en la discusión de su conferencia «Die Grundlage der Naturrechtslehre», impartida en 1962 y publicada en 1963. Dice ahí, muy expresivamente: «en mis escritos anteriores he hablado de normas que no son el sentido de actos de voluntad. He presentado toda mi doctrina de la norma fundamental como una norma que no es el sentido de un acto de voluntad, sino que es presupuesta en el pensamiento. Ahora, desgraciadamente, debo admitir, señores míos, que no puedo seguir manteniendo esa doctrina, que debo abandonarla (...). La he abandonado ante la conciencia de que un deber ser ha de ser el correlato de un querer. Mi norma fundamental es una norma ficticia, que presupone un acto de voluntad ficticio que dicta esta norma. Es la ficción de que una autoridad quiere que esto deba ser (...). Tuve que modificar mi exposición de la doctrina de la norma fundamental. No pueda haber normas meramente pensadas, es decir, normas que sean el sentido de un acto de pensamiento, no el sentido de un acto de voluntad. Lo que se piensa con la norma fundamental es la ficción de un acto de voluntad que realmente no existe» («Die Grundlage der Naturrechtslehre»). (GARCÍA AMADO, 1996, p. 104, nota 138$)$.

Dito isso pelo próprio jurista, torna-se impossível negar que a solução transcendental cai por terra: uma categoria jamais pode ser, em sentido kantiano, uma ficção. Curioso e ao mesmo tempo esclarecedor, a essa altura, é o fato de que, em suas concepções prematuras (em 1911), Kelsen não enxergava o fundamento de validade como solução a priori. Naquele que García Amado identifica como o primeiro texto em que Kelsen introduz a questão do fundamento de validade, quando ainda não o chamava Grundnorm, ele diz que "la elección de este punto de vista no es básicamente una cuestión jurídica, sino política, y por ello tendrá siempre la apariencia de arbitrariedad de vista del conocimiento jurídico". ${ }^{14}$ Note-se que, à diferença do já analisado problema da norma fundamental ser disponível, nesse trecho Kelsen admite que a adoção da norma fundamental representa uma verdadeira opção, arbitrária e não necessária, desde dentro

14 Segundo o autor, esse texto seria «Reichgesetz und Landesgesetz nach österreichischer Verfassung», Archiv des öffentliches Recht, de 1914. cf. GARCÍA AMADO, Juan Antonio. Kelsen y la norma fundamental. Madrid: Marcial Pons, 1996. p. 57. 
do próprio conhecimento jurídico, por meio do próprio método normativo, diferentemente daquele trecho anteriormente citado, em que Kelsen dizia que se pode pressupor a norma fundamental, mas caso não se a pressuponha, não se trata mais de conhecer o direito.

Assim, parece que Kelsen partiu inicialmente de um postulado político, em seguida buscou uma fundamentação kantiana, para depois capitular ante as antinomias que os próprios conceitos kantianos implicavam para o conceito de norma de sua teoria jurídica. Esse certamente foi um dos momentos mais caros aos críticos de Kelsen, principalmente àqueles de orientação realista ou crítica, que não viam o Direito e o Estado com base em fundamentos transcendentais.

\section{Quem pressupõe a norma fundamental?}

A fundamentação da ruína do argumento transcendental tem mais pontos de apoio. Um outro problema a ser analisado é: quem pressupõe a norma fundamental? Como foi visto, se a norma fundamental é uma norma baseada numa vontade meramente pensada, surge o grande inconveniente de essa ser uma norma criada pela ciência do direito, ao preço de tornar nebuloso o próprio conceito kelseniano de ciência, que apenas poderia descrever seu objeto, nunca inventá-lo. Esse problema da pressuposição da norma fundamental deve passar pela análise dos dilemas do próprio positivismo de Kelsen.

Na Teoria Pura do Direito, Kelsen diz que ora é a ciência do direito que a pressupõe, ora são os intérpretes em geral, inclusive os operadores, juízes e populares. Por isso, Stanley Paulson deu uma natureza pluridimensional ao conceito:

De una concepción consistente de la norma fundamental junto con los tres mencionados puntos de vista surge un concepto pluridimensional de la norma fundamental, que luego en diferente manera se dirige a tres grupos de destinatarios: al dador del derecho (dinâmico), al científico del derecho (estático) y no por último al sujeto del derecho (normativo). (PAULSON, 2000, p. 183).

Ocorre que isso vai refletir uma grande antinomia na teoria pura. E García Amado bem identifica isso entre os comentadores de Kelsen. Se a ciência do direito pressupõe a norma fundamental - e Kelsen o afirma em trechos como: "Constatar essa pressuposição é uma função essencial da ciência jurídica” (KELSEN, 1960, p. 77) — isso implica que de alguma forma a ciência põe a norma, cria-a, pois ela não está na realidade, mas é uma norma fundada no pensamento. Se há então uma vontade pensada teoricamente, a ciência do direito viola o postulado descritivo da teoria de Kelsen, uma vez que:

Como teoria, quer única e exclusivamente conhecer o seu próprio objecto. Procura responder a esta questão: o que é 
e como é o Direito? Mas já não lhe importa a questão de saber como deve ser o Direito, ou como deve ele ser feito. É ciência jurídica e não política do direito" (KELSEN, 1960, p. 17, cap. 1, item 1).

Assim o conhecimento do direito passa a ser também criação do direito. Ainda que esse conflito teórico não tenha se apresentado de forma consciente nos textos de Kelsen, de alguma forma o autor tem de defender que essa pressuposição não é criada, mas apenas constatada pela ciência a partir da sua aplicação na realidade pelos órgãos do direito em geral. Isso é o que Kelsen parece afirmar ao responder à sua própria pergunta acerca de quem pressupõe a norma fundamental: "todo aquele que pensa (interpreta) o sentido subjectivo do acto constituinte e dos actos postos de acordo com a Constituição como seu sentido objectivo, quer dizer, como normas objectivamente válidas". (1960, p. 284, nota; cap. V, item 34, letra d). Ou ainda: "Simplesmente tornamos explícito o que todos os juristas pressupõem, a maioria deles involuntariamente, quando consideram o Direito positivo como um sistema de normas válidas (...)” (1945, p. 170, cap. X, C-b.).

Essa argumentação, todavia, é precária. Seja como for, para evitar analisar a obra de Kelsen nesse nível de sutis detalhes textuais aqui e ali, o que aqui se defende é que, objetivamente, isto é, independentemente do que Kelsen realmente quis expressar nesses diversos trechos, certamente há um problema de incompatibilidade entre o conceito de norma como sentido de uma vontade pensada e o conceito de ciência descritiva, que identifica normas a partir de vontades reais, levando a crer que nessa citação problemática Kelsen teria percebido o problema de ser ela pressuposta pelo cientista e não pelos operadores do direito.

A partir dessa alternativa, visualizam-se mais problemas para além do juízo sobre a natureza transcendental da norma fundamental — e aqui já se está a julgar se o conceito de validade kelseniano, além de não ser transcendental, é ainda útil. Primeiramente, na visão de Santiago Nino, se são os operadores do direito ou o povo aqueles que pressupõem a norma fundamental, então o raciocínio de validade das normas derivadas do sistema vai também ser em termos hipotéticos (ou fictícios). Se a validade implica de algum modo uma obrigatoriedade, compromete-se o conceito ao se passar uma hipótese para o raciocínio do operador do direito:

«Un razonamiento práctico cuya premisa mayor sea una norma aceptada sólo hipotéticamente (...) no puede arrojar conclusiones categóricas sino también hipotéticas, por lo que no puede servir para justificar acciones o decisiones»» (SANTIAGO NINO, Derecho moral y politica, Barcelona Ariel, 1994, p. 107, apud GARCÍA AMADO, 1996, p. 113, nota 153$)$.

Em outras palavras, se é o povo ou o operador quem assume uma hipótese, a noção de validade como obrigatoriedade desaparece, pois o objeto de estudo dessa 
ciência, que implica a descrição do dever, terá passado à descrição de hipóteses, em última análise assumidas por todos os cidadãos da ordem jurídica. E hipóteses não obrigam.

Desse modo, é a necessidade da vontade na norma fundamental que torna o conceito problemático segundo essas críticas. Se for a ciência do direito que a pressupõe, então a ciência, em última análise, cria norma; se for o povo, então a racionalidade da validade do mesmo modo desaparece para dar lugar a um voluntarismo que enfraquece a noção de dever-ser, já que a obrigatoriedade é, em última análise, fictícia.

Esse problema de uma ciência que em última análise cria uma norma é analisado cuidadosamente por Santiago Nino, que de certa forma apresenta uma possível defesa de Kelsen:

Aun cuando Kelsen no es muy claro sobre esto, dudo mucho de que le entusiasmara la extensión de la clase de personas que deberían aceptar la norma básica; una cosa es razonar teóricamente de acuerdo con la presuposición de que un sistema eficaz está justificado y otra cosa es actuar según esa presuposición; ... (NINO, 1985, p. 23).

Mas o próprio jurista argentino reconhece que essa distinção entre a ação do juiz e o raciocínio do teórico, no limite, não existe:

... en el último caso no hay diferencia significativa entre presuponer meramente que el sistema está justificado y aceptar plenamente esa justificación, y decir que los tribunales deben presuponer la norma básica con referencia a los sistemas eficaces equivale a decir que deberían actuar de la misma forma que si creyeran que el sistema está justificado. (NINO, 1985, p. 23).

Esse problema de uma diferença entre razão, crença e ação desdobra-se ainda em mais dificuldades, pois, para alguns, remete a uma união entre direito e moral no fundamento de validade. Desse modo, se a norma fundamental é o sentido de uma vontade pressuposta, ficta, sentida como obrigatória, e se é impossível garantir seu status transcendental, então ela é um recurso que necessariamente se confunde com um poder fundante, do qual Kelsen pretendia fugir de toda maneira para não ser acusado de político. E as críticas nesse sentido não passaram desapercebidas por Bobbio, que remodela toda a teoria kelseniana em fundamentos hobbesianos:

Com'è noto, la norma fondamentale è stata il bersaglio di tante critiche. Di tutte le critiche a me pare che la piú pertinente sia quella che la ritiene un espediente ingegnoso ma tutto sommato perfettamente inutile. Non si capisce infatti per quale ragione, se non quella di una pura correttezza formale, sia necessario chiudere l'ordinamento giuridico con una norma ultima, anziché con unpotere ultimo quando poi ciò che alla fine consente d'identificare un ordinamento 
come ordinamento giuridico non è la validità delle norma ma la loro efficacia, il che val qualto dire che ciò che chiude il sistema non è una norma ma un potere. (BOBBIO, 1992, p. 120).

Assim se nota que a busca por um modelo kelseniano clássico não é possível sem uma leitura crítica dos principais problemas que esse modelo apresentou no curso do século XX. O principal argumento kelseniano, o transcendental, se colocado em xeque, permite compreender melhor uma série de outras críticas que a Teoria Pura do Direito sofreu quanto à sua metodologia científica:

a) A crítica à sustentabilidade de um argumento juspositivista, apto a evitar uma argumentação moral;

b) A crítica à normatividade baseada na coerção, numa problemática dependência do dever-ser em relação ao mundo da efetivação pela via da sanção no mundo do ser;

c) A crítica à necessária relação do dever-ser com a efetividade tanto da norma individual como de todo o sistema baseado na norma fundamental, ou seja, o problema do empirismo kelseniano;

d) Por fim, a crítica à racionalidade lógica interna dos ordenamentos jurídicos segundo uma teoria pura, isto é, a própria condição epistemológica de um projeto racionalista conhecer o direito como realmente ele é, ou o problema da lógica jurídica em Kelsen.

Essas questões, somadas com aquelas enfrentadas nesse trabalho, formam um segundo bloco de problemas que completam o conjunto total das críticas que os juristas do século XX teceram à Teoria Pura do Direito e que merecem, portanto, uma abordagem que não convém desdobrar nos limites da proposta.

São suficientes, assim se espera, para aguçar o interesse do jovem leitor que se inicia nas grandes questões da história recente da teoria do direito e que pode encontrar em Kelsen um pensador fundamental para a compreensão dos rumos da filosofia do direito dos dias atuais, a qual continua em busca de explicações sobre as principais perguntas respondidas pelo jurista austríaco, considerado um dos maiores juristas de todos os tempos por ter erguido um monumento teórico que permaneceu vivo e influente por quase todo o século XX.

São Paulo, março de 2014. 


\section{Referências}

ABBAGNANO, Nicola. História da filosofia. Lisboa: Presença, 1995. v. 8, 12.

ALCHOURRÓN, Carlos; BULYGIN, Eugenio. Introducción a la metodología de las ciencias jurídicas y sociales. Colección mayor Filosofía y Derecho. Buenos Aires: Astrea, 1998.

ALVES, Alaôr Caffé. Linguagem, sentido e realidade da norma jurídica: dialética da norma jurídica. 1996. Tese (Livre Docência) - Faculdade de Direito, Universidade de São Paulo, São Paulo.

ALVES, Alaôr Caffé. Lógica: pensamento formal e argumentação. Bauru: Edipro, 2000.

AYALA, Ricardo Azpúrua. Kelsen y su posición frente al positivismo y la dirección neokantiana. Revista de Ciencias Sociales, Universidad de Chile, Valparaiso, n. 6, p. 29-53, Dic. 1974.

BOBBIO, Norberto. Diritto e potere: saggi su Kelsen. Napoli: Edizioni Scientifiche Italiane, 1992. . O positivismo jurídico, São Paulo: Icone, 1995.

. Teoria general del derecho. Bogotá: Temis, 1987.

CARRINO, Agostino. Vita e forme in Kelsen. In: KELSEN, Hans. Dio e stato: la giurisprudenza come scienza dello spirito. Trad. A. Carrino. Napoli: Edizioni Scientifiche Italiane, 1988.

EBENSTEIN, William. La teoría pura del derecho. México-B. Aires: Fondo de Cultura Económica, 1947.

ECHEVERRÍA, Manuel. Kelsen y los juristas mexicanos. México: UNAM, 1968.

FERRAZ JR., Tercio Sampaio. Introdução ao estudo do direito. São Paulo: Atlas, 1994.

GARCÍA AMADO, Juan Antonio. Kelsen y la norma fundamental. Madrid: Marcial Pons, 1996.

GOYARD-FABRE, Simone. Kelsen e Kant: saggi sulla dottrina pura del diritto. Napoli: Edizioni Scientifiche Italiane, 1993.

GUIBOURG, Ricardo. Derecho, systema y realidad. Buenos Aires: Astrea, 1986.

HART, Hebert L. A. Visita a Kelsen. Tradução por Leonel Cesarino Pessoa do original Kelsen Visited. Essays in Jurispdrudence and Phylosophy. Oxford: Clarendon.

INSTITUTO Hans Kelsen. Teoría pura del derecho y teoría marxista del derecho. Bogota: Temis, 1984.

KANT, Immanuel. Crítica da razão pura. Trad. Valerio Rohden e Udo B. Moosburger. São Paulo: Nova Cultural, 1999. (Coleção “Os Pensadores”).

. A metafísica dos costumes. Tradução, textos adicionais e notas Edson Bini. 2. ed. Bauru: Edipro. 2008. 
KELSEN, Hans. Dio e Stato: la giurisprudenza come scienza dello spirito. Napoli: Edizioni Scientifiche Italiane, 1988.

Introduction to the problems of legal theory. Trad. de Reine Rechtslehre por Bonnie L. Paulson e Stanley L. Paulson. Oxford: Clarendon Press, 1992.

. La giurisprudenza come scienza normativa o culturale: studio di crítica metodologica. In: Dio e Stato: la giurisprudenza come scienza dello spirito. Trad. A. Carrino, Napoli: Edizioni Scientifiche Italiane, 1988.

. Hauptprobleme der Staatsrechtslehre, entwickelt aus der Lehre vom Rechtssatz. 2. ed. Tübingen: Mohr, 1923. XVII.

. Teoría general del derecho y del Estado. Trad. Eduardo García Máynes. México: Unam, 1969.

. Teoria geral das normas. Porto Alegre: SAFE, 1986.

. Teoria geral do direito e do Estado. São Paulo: Martins Fontes, 1998.

. Teoría pura del derecho. Buenos Aires: Losada, 1941.

. Teoria pura do direito. Coimbra: Arménio Amado, 1984.

; KLUG, Ulrich. Normas jurídicas e análise lógica. Rio de Janeiro: Forense, 1984.

LEGAZ Y LACAMBRA, Luis. Kelsen: estudio crítico de la teoría pura del derecho y del Estado de la Escuela de Viena. Barcelona: Bosch, 1933.

MARTÍN, Nuria Belloso. La validez del derecho: del normativismo y realismo jurídico a una concepción filosófica. Nomos: Revista do Curso de Mestrado em Direito da UFC, Fortaleza, v. 15, n. $1 / 2$, jan./dez.1996.

NINO, Carlos Santiago. Introducción al análisis del derecho. Colección Mayor Filosofia Y Derecho. Buenos Aires: Astrea, 1998.

. La competencia del poder originario y el carácter moral de la justificación jurídica. In: $L a$ validez del derecho. Colección Mayor Filosofia Y Derecho. Buenos Aires: Astrea, 1985.

OLIVEIRA, Manfredo Araújo de. Lógica Transcendental e lógica especulativa. In: Cadernos da UnB: Kant. Brasília: UnB, 1980.

PAULSON, Stanley L. Fundamentación crítica de la doctrina de Hans Kelsen. Bogotá: Universidad Externado de Colombia, 2000. (Série de Teoría Jurídica y filosofia del derecho, n. 17).

. Introduction: on Kelsen's Place in Jurisprudence. In: KELSEN, Hans. Introduction to the problems os legal theory. Trad. Bonnie L. Paulson e Stanley L. Paulson. New York: Oxford University, 1992. 
REALE, Miguel. A visão integral do direito em Kelsen. In: PRADO, Luiz Régis; KARAM, Munir. (Coord.). Estudos de filosofia do direito: uma visão integral da obra de Hans Kelsen. São Paulo: Revista dos Tribunais, 1985.

SICHES, Luis Recaséns. Panorama del pensamiento jurídico en el siglo XX. México: Porrua, 1963. t. 1.

STERIAD, Alice. Interprétation de la doctrine de Kant par l'École de Marburg (étude sur idéalisme critique). Paris: M. Giard \& E. Brière, 1913.

VERNENGO, Roberto José. Kelsen`s Rechtssätze as Detached Statements. In: TUR, Richard; TWINING, William. Essays on Kelsen. Oxford: Clarendon, 1986.

WALTER, Robert. Kelsen, la teoría pura del derecho y el problema de la justicia. Bogota: Universidad Externado de Colombia, 1999.

. La doctrina del derecho de Hans Kelsen. Bogotá: Universidad Externado de Colombia, 1999. (Série de Teoría Jurídica y filosofia del derecho, n. 13).

WILSON, Alida. Is Kelsen really a Kantian? In: TUR, Richard; TWINING, William (Org.). Essays on Kelsen. Oxford: Clarendon Press, 1986.

WINDELBAND, Wilhelm. Normen und Naturgesetze. In: . Präludien. Aufsätze und Reden zur Philosophie und ihrer Geschichte. Tübingen: Mohr, 1915. v. 2, p. 59-98. 
